NBER WORKING PAPER SERIES

\title{
UNDERSTANDING THE RISE IN CORPORATE CASH: PRECAUTIONARY SAVINGS OR FOREIGN TAXES
}

\author{
Michael W. Faulkender \\ Kristine W. Hankins \\ Mitchell A. Petersen \\ Working Paper 23799 \\ http://www.nber.org/papers/w23799 \\ NATIONAL BUREAU OF ECONOMIC RESEARCH \\ 1050 Massachusetts Avenue \\ Cambridge, MA 02138
}

September 2017, Revised August 2018

\begin{abstract}
Previously circulated as "Understanding Precautionary Cash at Home and Abroad." The statistical analysis of firm-level data on U.S. multinational companies was conducted at the Bureau of Economic Analysis, U.S. Department of Commerce, under arrangements that maintain legal confidentiality requirements. The views expressed in the paper are those of the authors and do not reflect official positions of the U.S. Department of Commerce. We appreciate the suggestions and advice of Chris Anderson, Alice Bonaimé, Sergey Chernenko, Beverly Clingan, Laurent Fresard, Craig Furfine, Gustavo Grullon, Kathleen Kahle, Stephen Karolyi, Chris Parsons, Rene Stulz, Rohan Williamson, William Zeile, the referee, and the editor (David Denis) as well as seminar and conference participants at the American Finance Association, Dartmouth University, Federal Reserve Board of Governors, Florida State University, Georgetown University, Georgia Institute of Technology, Louisiana State University, Midwest Finance Association, Northeastern University, Northwestern University, Ohio State, Rice University, the Securities and Exchange Commission, the Shanghai Advanced Institute of Finance, the Swiss Finance Institute, and the Universities of Alberta, Cincinnati, Illinois-Chicago, Illinois-UC, Iowa, Kansas, Miami, Oklahoma, Pennsylvania, Pittsburgh, Oregon, San Diego, Southern California and South Carolina. The research assistances of Austin Magee, Sang Kim and Mark Scovic is greatly appreciated. Kristine Hankins also thanks the Institute for the Study of Free Enterprise for financial support. The views expressed herein are those of the authors and do not necessarily reflect the views of the National Bureau of Economic Research.
\end{abstract}

NBER working papers are circulated for discussion and comment purposes. They have not been peer-reviewed or been subject to the review by the NBER Board of Directors that accompanies official NBER publications.

(C) 2017 by Michael W. Faulkender, Kristine W. Hankins, and Mitchell A. Petersen. All rights reserved. Short sections of text, not to exceed two paragraphs, may be quoted without explicit permission provided that full credit, including $\odot$ notice, is given to the source. 
Understanding the Rise in Corporate Cash: Precautionary Savings or Foreign Taxes

Michael W. Faulkender, Kristine W. Hankins, and Mitchell A. Petersen

NBER Working Paper No. 23799

September 2017, Revised August 2018

JEL No. G31,G32,G35

\section{ABSTRACT}

What has driven the dramatic rise in U.S. corporate cash? Using non-public data, we show that the run-up is not uniform across firms but is concentrated in the foreign subsidiaries of multinational firms. Standard precautionary motives explain only domestic cash holdings, not these burgeoning foreign cash balances. Falling foreign tax rates, coupled with relaxed restrictions on income shifting, are the root of the changing foreign cash patterns. Firms with intellectual property have the greatest ability to shift income to low tax jurisdictions, and their foreign subsidiaries are where we observe the largest accumulations of cash.

Michael W. Faulkender

University of Maryland

RH Smith School of Business

4417 Van Munching Hall

College Park, MD 20742

mfaulken@rhsmith.umd.edu

Kristine W. Hankins

University of Kentucky

Lexington, KY 40506

kristine.hankins@uky.edu
Mitchell A. Petersen

Kellogg School of Management

Northwestern University

2001 Sheridan Road

Evanston, IL 60208

and NBER

mpetersen@northwestern.edu 
According to recent Flow of Funds estimates, U.S. non-financial corporations are sitting on an aggregate cash and marketable securities position of close to $\$ 4$ trillion (see Figure 1). This staggering amount has led policy makers and commentators to express concern as to why firms are building such large stockpiles. To explain the dramatic rise in cash, it is first necessary to understand the factors that cause firms to hold cash.

In a world of capital market frictions and uncertain investment opportunities, holding cash enables firms to invest in value creating projects without delay. This precautionary savings story has been the primary focus of the academic literature. Earlier work focused on measuring firms' access to the capital markets (Opler et al., 1999), while more recent work has focused on the role of increasing investment uncertainty (Martin and Santomero, 1997; Boyle and Guthrie, 2003; Bates, Kahle, and Stulz, 2009; and Harford, Klasa, and Maxwell, 2014).

Not all cash is held for precautionary savings. Thus, uncertainty and financing frictions alone may not explain the huge run-up in corporate cash. Foley et al. (2007) and Graham and Leary (2017) explore foreign taxes as an alternative explanation for why firms hold cash. The United States taxes the income of foreign subsidiaries, but only when the income is repatriated. ${ }^{1}$ Thus, when the foreign tax rate is less than the U.S. rate, there has been an incentive to delay repatriation (Faulkender and Petersen, 2012 and Graham, Hanlon, and Shevlin, 2010). Firms' objective to minimize the present value of taxes may result in a buildup of cash in foreign subsidiaries - often called "trapped cash." Foley et al. (2007) show in a cross-sectional time-series regression that lower foreign tax rates are associated with higher total and higher foreign cash.

Our research bridges these two distinct explanations. The literature has characterized investments in intellectual property $(\mathrm{R} \& \mathrm{D})$ as being more opaque and therefore contributing to the

\footnotetext{
${ }^{1}$ Following the passage of the Tax Cuts and Jobs Act of 2017, this is no longer true. Our sample predates the passage of this law. We discuss the potential implications of the tax reform given our results in Section V.
} 
demand for holding cash to fund future investments. Observing that the cash run-up is most acute at high $\mathrm{R} \& \mathrm{D}$ firms has given rise to the precautionary savings interpretation. Alternatively, the opacity of intangible assets may better facilitate income shifting to low tax countries. If so, the tax explanation would be more accurate.

To explore the immense growth in corporate cash, and to differentiate between the alternative explanations of that growth, we focus on where the cash is located. Theoretically, location matters. Foreign and domestic cash are perfect substitutes when the tax rates are equal and there is no incentive to delay repatriation. However, as foreign tax rates fell below U.S. rates, there has been an incentive not only to delay the repatriation of foreign income, but also to shift income into lower tax jurisdictions.

The empirical challenge is that observing domestic and foreign cash historically has not been possible using publicly available data sources. While some firms recently have voluntarily disclosed their foreign cash position (Harford et al. 2017), this selectively released data is limited in both scope and length. The Bureau of Economic Analysis (BEA) conducts a mandatory survey of U.S. multinational companies that generates the data that is needed to address this shortcoming. From this survey, we are able to measure the amount of cash and marketable securities that firms are holding in each foreign subsidiary. Combining this with the disclosure of their total cash and marketable securities position (from Compustat), we are able to calculate how much cash is held domestically.

We unpack the distinct channels that could be driving the rise in cash: growing international business activity, changing precautionary cash needs, declining foreign corporate tax rates, and lastly, active tax minimization behavior by U.S. corporations. The run-up in corporate cash has roots in each of these channels, but the last two are the dominant causes. We first show 
that the rise in total cash is due almost exclusively to a rise in foreign cash and then ask whether the factors that explain the level of total cash (precautionary savings or foreign taxes) apply equally to domestic and foreign cash. Here we find that the factors that drive the two decisions are quite distinct. Domestic cash is explained mainly by precautionary savings variables, while taxes explain foreign cash. ${ }^{2}$ There is very little evidence of precautionary motives explaining foreign cash holdings. Our estimates suggest that $79 \%$ of the increase in foreign cash $(4.1 \%$ of the overall $5.2 \%$ increase in the foreign cash to assets ratio) is explained by the reductions in tax rates that firms face on their foreign income over our sample period.

Having documented that the run up in cash is concentrated in foreign cash and that the motivations for holding foreign and domestic cash are different, we next delve further into why foreign cash has grown so rapidly. Higher foreign cash can arise due to a growth of international sales, a passive response to falling foreign tax rates, an active shifting of income to minimize taxes, or some combination of the three. If earning income in low tax foreign subsidiaries (at the cost of building cash up in these subsidiaries) can lower corporate tax obligations, why are not all firms doing this? There is evidence that intellectual property royalties and transfer payments facilitate the offshoring of income to low tax jurisdictions (Grubert, and Mutti, 1991; Levin and McCain, 2013; Kanter, 2014). Firms with intellectual property, whether it consists of patents, trademarks or licensing deals, may be better able to adjust the ownership and within-firm pricing of the IP to transfer income from more highly taxed regions to affiliates in low tax havens. Our exploration of the role of asset type (e.g. intangible assets) in facilitating these transactions reveals that

\footnotetext{
${ }^{2}$ Foley et al. (2007) are among the first to document that low foreign tax rates predict higher foreign cash levels. This result is from a panel data set regression. While they document the importance of foreign tax rates, they do not examine whether this is due to cross-section or time-series variation. Although Foley et al. (2007) and our paper both use BEA data, the empirical findings are quite different, most likely due to different sample periods and therefore tax regimes. In Section II, we highlight the differences in the results and explain the source of the differences.
} 
intercompany sales (related sales) and the associated income shifting is a factor only in firms that invest in $R \& D .{ }^{3}$ We document that $92 \%$ of the growth in foreign cash is concentrated in firms with both significant related sales and intangible assets. R\&D investments facilitate related sales to subsidiaries in countries with already low or declining foreign tax rates. The combination of all three of these elements (intangible assets, transfer pricing, and low tax rates) is what explains most of the rise of foreign cash.

The rest of this paper is organized as follows. Section I describes our data and empirical strategy. Section II presents our results, while the channel of affiliated sales and transfer pricing is explored in Section III. In Section IV, we examine the role of taxes and transfer pricing at the subsidiary level. We discuss potential responses by firm to the recent tax reform in light of our empirical results in Section V. The final section concludes.

\section{Empirical Strategy and Data}

\section{A. Empirical Design}

Our objective is to better understand the recent growth of firms' cash balances. In particular, we investigate the relative importance of tax motivations against alternative explanations. To distinguish between these motivations for holding cash, we separately estimate a model to explain a firm's total, domestic, and foreign cash holdings. These results allow us to test whether the motivations that drive firms to stockpile cash are the same for both domestic and foreign cash.

\footnotetext{
${ }^{3}$ The $R \& D$ variable has different interpretations in the literature. The finding that $R \& D$ predicts greater total cash has been interpreted as proxying for investment opportunities and capital market frictions in the precautionary savings literature (He and Wintoki, 2016). The tax literature points to R\&D and the associated intangible assets it creates as facilitating transfer pricing. Our results highlight the different role R\&D plays in explaining domestic versus foreign cash.
} 
To document the tax motivations for holding cash, we must measure the firm's incentive and the firm's ability to earn income in low tax jurisdictions. Following Faulkender and Smith (2016), we calculate the marginal tax rate a firm faces (the effective tax rate). The measure is a weighted average of the marginal statutory tax rate based on the firm's earnings before interest and taxes (EBIT) in each country. The weights are the percentage of EBIT generated in each affiliate in the corresponding fiscal year in the specified tax jurisdiction of that affiliate (e.g., subsidiary). ${ }^{4}$ Thus, if 50\% of EBIT in 2006 was generated in the United States, $30 \%$ in the Irish foreign affiliate, and the remaining $20 \%$ in the German affiliate, the estimated 2006 tax rate for this firm is:

$$
\tau_{\text {Firm, } 2006}=50 \% \tau_{\mathrm{US}, 2006}+30 \% \tau_{\text {Ireland,2006 }}+20 \% \tau_{\text {Germany }, 2006}
$$

The tax rates are the rate a firm pays on its last dollar of EBIT in each country. For the U.S., the marginal tax rate is $35 \%$ above $\$ 18.3 \mathrm{M}$ of income. The foreign tax rate schedules come from the KPMG Corporate and Indirect Tax Survey (1998 to 2005) and Comtax (2006 to 2008). This blended tax rate represents our estimate of the tax rate confronting firms prior to deducting interest expense or incorporating interest income. As this weighted average rate declines, we would expect the firm to hold more foreign cash because the realized deferral benefits are greater. Stated differently, firms that generate the greatest amount of earnings in low tax jurisdictions are the ones that would benefit most from deferring repatriation of those earnings and thus stockpiling the earnings in cash and marketable securities. Finding a negative relationship between a firm's effective tax rate (ETR) and its cash holdings would provide evidence consistent with this hypothesis.

\footnotetext{
${ }^{4}$ If EBIT is negative in a subsidiary, the weight is set to zero for that subsidiary. We combine all subsidiaries a firm has in a country into a single subsidiary for our analysis.
} 
We then estimate the total cash holdings of firms (as a percentage of their book assets) as a function of the effective tax rate and standard determinants of cash. ${ }^{5}$ We control for firm size (the natural log of sales), for whether the firm has a bond rating, for its asset tangibility (the ratio of PP\&E to book assets), profitability (return on assets), R\&D to sales, advertising to sales, market to book ratio, book leverage, and capital expenditure to assets. ${ }^{6}$ This data is from Compustat. All variables are winsorized at the $1^{\text {st }}$ and $99^{\text {th }}$ percentiles.

While the tax rate measures a firm's incentive regarding where to earn income, we also need to determine which kinds of firms are best able to manage their operations in a way that mitigates taxes and thus results in trapped foreign cash. Anecdotally, there is evidence that the effect is particularly pronounced in firms with high levels of intellectual property. Since such firms can move earnings from high tax to low tax jurisdictions using advantageous intracompany transfer pricing (or income shifting), we would expect significant sales from one subsidiary to another, relative to total sales, to be indicative of this type of international tax planning. We construct a measure (related sales) that is the percentage of the firm's total revenue that is derived from sales of its foreign subsidiaries, either to the parent or to its other foreign subsidiaries. We hypothesize that the tax effect should be greatest among those firms that are particularly adept at using related sales to move income across various tax jurisdictions. ${ }^{7}$

\section{B. Foreign Subsidiary Data}

\footnotetext{
${ }^{5}$ A related literature examines how the cash and marketable securities are invested. Duchin et al. (2017) find that some of the savings is held in risky and illiquid securities that may be a less valuable form of precautionary savings. When we measure cash, we include both cash and marketable securities.

${ }^{6}$ Precautionary savings traditionally has been interpreted as firms not distributing profits to investors (savings) to fund future potential investment. Young and high growth firms with access to the capital markets may also proactively raise capital to fund future investments and thus generate cash stockpiles (see Denis and McKeon, 2017).

7 The recent Tax Cuts and Jobs Act introduced a new Base Erosion and Anti-Abuse Tax, which is aimed at limiting $\mathrm{MNC}$ income shifting and applies to intercompany sales.
} 
The challenge to our empirical approach is the lack of publicly available data regarding the international operations of firms. The information disclosed in firms' 10-Ks is entirely too coarse to understand where firms are operating, the tax jurisdictions to which they are subject, and the amount of cash and marketable securities they hold in these various locations. Fortunately, the Bureau of Economic Analysis (BEA) conducts a mandatory annual survey of U.S. multinationals that contains numerous balance sheet and income statement items for each foreign affiliate of a U.S.-based multinational firm, including the amount of cash held in each foreign subsidiary. The U.S. multinationals are required by law to complete the survey.

The data comes from two BEA surveys: the benchmark surveys (BE-10) and annual surveys (BE-11). ${ }^{8}$ Since we are interested in the cash allocations of firms as well as variation in the foreign tax rates multinational firms confront, our firm-year observations are limited to the years during which the necessary data was gathered. This annual data is available from 1998 to 2008. After 2008, foreign cash balances are no longer collected. Using this data, we are able to measure the amount of cash and estimate the marketable securities held in their foreign subsidiaries. The annual survey (BE-11) reports the amount of cash in each foreign subsidiary as well as inventory and "other current assets." To estimate the marketable securities that are contained in other assets, we subtract an estimate of the subsidiary's accounts receivable from other assets, assuming the accounts receivable to sales ratio is the same across the firm. Our estimate of the cash and marketable securities is thus: ${ }^{9}$

$$
\text { Cash }+\left[\text { Other current assets- }-\left(\frac{\text { Accounts Receivable }_{\text {firm }}}{\text { Sales }_{\text {frrm }}}\right) \text { Sales }_{\text {Subsidiary }}\right]
$$

\footnotetext{
${ }^{8}$ The benchmark (BE-10) survey, conducted every five years (e.g. 1999 and 2004), has more comprehensive coverage of the accounting data for the smaller foreign subsidiaries than the annual (BE-11) survey, which is conducted in interim years. The BEA estimates these accounting items for the intervening four years between the comprehensive surveys. Our results are robust to restricting our sample to only the years in which the more comprehensive survey is conducted (see below).

${ }^{9}$ If this value is less than the reported cash value, we use the reported cash value.
} 
This approach assumes the rest of "other current assets," beyond accounts receivable, consists of marketable securities. ${ }^{10}$ In the benchmark survey, cash and the various components of marketable securities are separately reported. ${ }^{11}$ The difference between the total cash position of the firm and the sum of the cash in its foreign affiliates is our estimate of the firm's domestic cash position each year.

\section{Summary Statistics}

\section{Location of Cash Holdings}

With our data, we can document where the rise in cash is occurring. We examine geography first. Although both domestic and foreign cash have risen, the rise in foreign cash has been much greater. In Figure 2, we plot the cash held by purely domestic firms (non-MNCs), the domestic cash held by U.S. MNCs, and the foreign cash held by U.S. MNCs. Consistent with Figure 1, domestic cash held by both MNCs and non-MNCs displays growth faster than the economy, but not by a huge margin. Cash held by non-MNCs has risen by $80 \%$ over our sample period, and domestic cash held by MNCs has grown by $90 \%$. GDP has grown by $30 \%$ over the same period. The rise in foreign cash has been much more dramatic. It grew by $440 \%$. Fifty-seven percent of the rise in total cash and $85 \%$ of the rise in the cash held by MNCs is due to the rise in foreign cash.

Not only has foreign cash grown, but the countries in which foreign cash is held have changed as well. Using the BEA data, we can identify the specific countries where the foreign cash is held. In Table 1, we rank countries by their cash holdings. We report the percentage of total

\footnotetext{
${ }^{10}$ When we replicated our results using only cash, opposed to our estimate of cash and marketable securities from equation (2), they remained essentially unchanged.

${ }^{11}$ In the benchmark survey, our estimate of cash and marketable securities is cash plus other current receivables plus other current assets (which includes certificates of deposit) plus other equity investments (which includes the noncurrent portion of marketable securities, cash on deposit, CDs, and additional equity investments). In a small number of cases, our estimate of foreign cash is greater than total cash. In these cases, we define total cash as equal to foreign cash, and domestic cash as zero. Dropping these observations does not alter our main results.
} 
foreign cash held and the percent of total foreign sales originating in each country, for the top fifteen countries. The percent of cash and sales in the remaining countries is also reported. The data for 1998 (the first year of our sample) is reported in the left hand columns and for 2008 (the last year of our sample) in the right hand columns.

Firms do earn income and thus hold cash in a country for strictly economic reasons (e.g., the country is where the business and investments are located) rather than solely for active tax minimization. Among the countries with high cash balances in 1998, we see several large economies (e.g., the United Kingdom, Germany, France, Canada, and Japan). The fraction of foreign cash and the fraction of foreign sales are relatively similar across countries in 1998. For example, subsidiaries located in the United Kingdom held 14.6\% of total foreign cash (the highest fraction) and generated $14.8 \%$ of all foreign sales in 1998. Subsidiaries in the top six countries, sorted by foreign cash, held $52 \%$ of the foreign cash and generated $42 \%$ of the foreign sales.

Firms may also hold cash in foreign countries because their tax rates are low and thus repatriation is costly. Although we don't see strong evidence of this at the beginning of our sample, this effect is apparent by the end of our sample. By 2008, only one large economy, the United Kingdom, remains in the top six. The other five countries (Ireland, Bermuda, the Netherlands, Belgium, and Luxembourg) are smaller economies with top corporate tax rates well below the U.S. tax rate. ${ }^{12}$ It is also apparent that the correlation between sales and cash had weakened by 2008 . Although these countries are the location of most of the foreign cash (subsidiaries in the top six countries now hold $55 \%$ of the cash), they generate only $25 \%$ of the foreign sales (see Table 1 ). Some of the countries are particularly noteworthy. Irish subsidiaries hold $13.1 \%$ of the cash, but

\footnotetext{
${ }^{12}$ The corporate tax rates we use in our analysis are marginal statutory corporate tax rates that subsidiaries would face on their next unit of income. If firms have negotiated (face) lower tax rates due to tax holidays, then we will underestimate the incentive to move income to such low tax jurisdictions. We return to this issue in Section III-C.
} 
generate only $4.0 \%$ of the sales in 2008; subsidiaries in Luxembourg hold $5.5 \%$ of the cash, but generate only $0.5 \%$ of foreign sales in 2008 .

Part of the shift between 1998 and 2008 was caused by firms increasing their stockpile of cash in countries that had low tax rates even in 1998 (i.e. the percentage of cash held in Bermuda doubles over our sample period). Foreign tax rates also fell relative to U.S. rates. The average top corporate tax rate across the fifteen countries with the most cash in 1998 (see Table 1) dropped from $38.7 \%$ to $29.0 \%$ between 1998 and 2008 (see Figure 3). The drop in tax rates among the six countries with the most cash drops is even greater (38.3\% to $15.7 \%)$ due to the shift of cash to low tax jurisdictions. During this period, the U.S. corporate tax rate did not change. The decline in foreign tax rates is significant. For example, between 1998 and 2008, the effective tax rate dropped from $32 \%$ to $12.5 \%$ in Ireland, from $35 \%$ to $24.3 \%$ in the Netherlands, and even Germany's tax rate dropped from $56.6 \%$ to $30.9 \% .^{13}$

In addition to geographic location, we find foreign cash is not uniformly distributed across industries. Our sample includes firms from 62 2-digit SIC industries. Within this sample, $86 \%$ of cash is held by firms in only nine industries; $70 \%$ is held by firms in only five industries (see Supplementary Table 1). These industries also have high foreign income, but cash is more asymmetrically distributed than income. The top nine industries sorted by foreign cash generate $32 \%$ of their income abroad, compared to $13 \%$ for the rest of the sample. In Table 2 , we found that MNCs actually have lower R\&D and lower market to book ratios, whereas the firms with large foreign cash holdings are often described as investing in mainly intangible assets. We see evidence of intangible assets when we look at the industries that have the most foreign cash (see Supplementary Table 1). The industry names are not obvious at first since the 2-digit industries

\footnotetext{
${ }^{13}$ The tax rates are taken from the OECD web site (stats.oecd.org) and we use the top corporate tax rate.
} 
are quite broad. However, subsectors of the top industries are ones commonly associated with intangible assets. The top industries include: Chemical and Allied products (e.g., pharmaceuticals), Industrial Machinery and Equipment (e.g., computer hardware), Business services (e.g., computer software), and Food \& Kindred products (e.g., beverages). In Section III, we will discuss how intangible assets contribute to the rise in corporate cash.

\section{Firm Characteristics: MNC and non-MNC}

Since most of the increase in cash is among MNCs, it is first necessary to understand how MNCs differ from other firms. These differences may help us understand the motivations behind firms' cash holdings and the reasons that contributed to the rise in cash balances. ${ }^{14}$ Total cash to assets is approximately the same in the full sample and the MNC subsample $(22.5 \%$ versus $21.1 \%$, see Table 2). The MNCs have significantly higher foreign cash $(8.9 \%$ versus $1.5 \%$ in the full sample) and less domestic cash, with MNCs holding $42 \%$ of their cash abroad. ${ }^{15}$ Since MNCs are larger, the fraction of cash held abroad is even larger when we look at total cash (weighting each dollar equally opposed to each firm equally). In this case, $64 \%$ of the MNC's cash is held abroad. This ratio rises from $54 \%$ to $74 \%$ over our sample period. Foreign cash holdings are concentrated in a subset of MNCs, an issue we will explore below.

Multinational and domestic firms differ by more than size. Compared to domestic firms, firms with foreign operations are more profitable, more likely to pay dividends, and more likely to

\footnotetext{
${ }^{14}$ Pinkowitz, Stulz, and Williamson (2016) compare the cash holdings of U.S. and foreign MNCs to determine if firm characteristics or country characteristics explain differences in cash holdings across countries. They also present evidence that non-R\&D firms and R\&D firms are not comparable in terms of how much cash they hold. They show that U.S. MNCs and foreign MNCs hold similar amounts of cash once the high R\&D U.S. MNCs are excluded.

${ }^{15}$ The magnitudes of cash holdings in our sample and in Foley et al. (2007) are quite different. In our sample, the total cash to net asset ratio is higher by a factor of almost four (22.5\% in Table 2 versus $5.7 \%$ in their Table 1$)$ and the average foreign cash to net asset ratio of MNCs is larger by a factor of over nine $(8.9 \%$ in our Table 2 versus $0.7 \%$ mean, $1.0 \%$ median in their sample). The dependent variable in their paper is the natural log of cash to assets (or foreign cash to assets). Thus, to make the numbers comparable we took the exponent of their mean or median (e.g. $\exp (-2.8687)=5.7 \%)$.
} 
have access to the bond market (i.e., a bond rating), while also having less volatile cash flows. These firm characteristics are normally associated with greater capital market access, not less. MNCs invest less in capital expenditures and R\&D. Thus, the average MNC does not appear to be a capital-constrained firm, yet these firms are responsible for a majority of the rise in cash.

\section{Determinants of Cash Levels: By Location}

\section{A. Precautionary Motives}

To understand the motivations for holding cash, we first regress total cash and marketable securities on firm characteristics that, in the prior literature, have been shown to explain the cash position of firms. As we investigate the determinants of firms' cash holdings, we will examine variation across firms with and without foreign operations. Among the firms with foreign operations, we can examine the determinants of their domestic and foreign cash holdings. This allows us to compare our results to prior work and highlight where the results are similar and where they differ. Consistent with prior work such as Bates, Kahle, and Stulz (2009), we find evidence of a precautionary motive for stockpiling cash when looking at the total cash held by a firm. Firms which should have greater access to the capital markets (are larger, have a bond rating, have greater asset tangibility [higher PPE/book assets and lower market to book ratio]) as well as those that invest less and/or return more capital to investors (lower R\&D, lower capital expenditure, and pay higher dividends) hold less cash. Traditionally, these results have been interpreted as consistent with the precautionary savings motivation because these firms are less likely to be capital rationed and thus benefit less from stockpiling cash. The results are broadly consistent whether we examine 
all firms (see Table 3, column I) or only multinational firms (firms with foreign profits: see Table 3, column II) ${ }^{16}$

Having established that the results are consistent with the prior literature that examined total cash holdings (e.g. Compustat data), we can now explore whether the determinants of cash holdings are the same for domestic and foreign cash. In the remaining columns of Table 3 , we run the regressions for domestic and foreign cash separately. The first thing to note is that many of the variables that are related to precautionary motives are relevant only for explaining domestic cash. The precautionary savings motivations are a significant determinant of the observed variation in the domestic cash of firms whether we look at all firms (Table 3, column III) or only multinational firms (column IV). Firms that are larger, have greater asset tangibility (PPE/book assets), pay dividends, conduct less R\&D, have lower market to book ratios, have lower capital expenditure, and have higher leverage ratios all hold less domestic cash. ${ }^{17}$ The economic effects are large as well. For example, increasing R\&D by one standard deviation ( 0.597 from Table 2 , full sample) leads to an 8.1 percentage point increase in cash to assets $(0.136 * 0.597=0.081)$ for all firms (Table 3, column III). This ratio is large compared to the average domestic cash to asset ratio of $21 \%$ (Table 2). These results are consistent with the types of firms most likely to be constrained holding more domestic cash in order to mitigate potential underinvestment that may result from such rationing.

\footnotetext{
${ }^{16}$ The standard errors are clustered by firm. We also estimate White standard errors, standard errors clustered by year, and standard errors clustered by firm and year (Petersen, 2009). Consistent with a firm effect, the T-statistics fall (the standard errors rise) when we cluster by firm relative to White standard errors. For example, the T-statistic on R\&D falls from 73.6 to 43.6 and the T-statistic on the effective tax rate falls from 18.5 to 9.9 (column I). Clustering by year produces T-statistics that are slightly larger than when we cluster by firm and smaller than when we use White standard errors (e.g. the T-statistic on the effective tax rate is 11.7 when standard errors are clustered by year). Clustering by both firm and year produces T-statistics that are slightly smaller than clustering by only firm. The largest change occurs for the effective tax rate, where the T-statistic falls from 9.9 to 8.3. This pattern of results is consistent across the following tables.

${ }^{17}$ If we do not include the firm's leverage, the results are even stronger (e.g., the coefficients are larger in magnitude).
} 
The precautionary savings variables, which are key to explaining the level of domestic cash, have little predictive power in explaining foreign cash positions (see Table 3, column VI). The coefficients either shrink, lose statistical significance, or flip signs (e.g. firm size). Firms with more tangible assets (PPE/Assets) hold statistically significantly less foreign cash, although the coefficient is $56 \%$ smaller than for domestic cash (column IV). Growth proxies (the R\&D-to-sales ratio and the market to book ratio) have small estimated coefficients that are no longer statistically significant (even though the standard errors are the same or smaller). In addition, the coefficients on variables explaining capital rationing — such as whether the firm pays dividends and the level of leverage—-have shrunk in magnitude and are no longer statistically significant.

In addition to the Table 3 baseline variables, there are other ways to measure precautionary savings motives (e.g., credit rationing or investment risk). For example, the literature has found that firms whose standard deviation of cash flow (measured over the preceding five years) hold more domestic cash (Bates, Kahle, and Stulz, 2009). We find the same effect. The coefficient is both statistically and economically significant (Table 3, column V). A one standard deviation increase in cash flow volatility increases the domestic cash to assets ratio by 1.6 percentage points $(0.169 * 0.097)$. Cash flow volatility has no effect on the amount of foreign cash firms hold nor does it change the magnitude of the coefficient on the effective tax rate (Table 3, column VII). ${ }^{18}$

\footnotetext{
${ }^{18}$ Supplementary Table 2 contains two additional measures of precautionary saving from the literature: the fraction of the prior three years during which the firm's internal cash flow (EBITDA - taxes - capital expenditure) was insufficient to finance their investment (Faulkender and Petersen, 2012) and product market fluidity, a forwardlooking measure of product market risk (Hoberg, Phillips, and Prabhala, 2014). As with the prior results, we find that firms that are more constrained by the capital markets or face greater investment uncertainty, hold more domestic cash (Supplementary Table 2, column I and III). Greater product market fluidity leads to a statistically significant decline (opposed to an increase) in foreign cash, but the magnitude is tiny. These additional controls, however, do not change the coefficient on the effective tax rate. No matter how we control for precautionary motives, lower foreign tax rates lead to significantly larger foreign cash balances (compare Table 3, column VI to Supplementary Table 2, columns II and IV).
} 
The explanatory variables thus far are all measured at the firm level. In many cases, this is because they measure the firm's access to the capital market (e.g. firm size, asset tangibility, and the existence of a bond rating). However, the intensity and type of investment of the subsidiary may differ from that of the entire firm. To test if the firm-level variables are such noisy measures that they drive the precautionary savings variables to zero, we rerun the regression only using observations where the foreign income is above the median (see Table 3, column VIII). For these observations, the firm-level variables are more closely associated with the subsidiary-level variables. The explanatory power of the precautionary saving variables does not improve, and in two cases, it shrinks. ${ }^{19}$

In sum, the precautionary motives are an important determinant of a firm's domestic cash holdings (whether a firm is MNC or not), but not of its foreign cash holdings. This is not to say that foreign cash cannot in theory provide precautionary savings. Multinationals, such as Apple, have borrowed with the market knowing they hold foreign cash (Lattman and Eavis, 2013 and Worstall 2015). However, foreign cash is not viewed as a source of cheaply accessible savings due to the tax cost of repatriation, and precautionary cash needs do not explain the observed growth in corporate foreign cash. ${ }^{20}$

\section{B. Foreign Tax Effects}

Firms with lower effective tax rates hold more cash in total, but this effect is due entirely to the foreign cash of MNCs. While we see lower effective tax rates raise foreign cash levels, there

\footnotetext{
${ }^{19}$ The capital expenditure variable is no longer statistically significant and the coefficient on PPE/assets shrinks by an additional $63 \%$. We do observe PPE/assets, R\&D, and sales at the subsidiary level. We return to this issue in Section $\mathrm{IV}$, but the conclusion that precautionary savings does not drive foreign cash is unchanged.

${ }^{20}$ Firms with more foreign cash do not increase their domestic liabilities to access this cash (De Simone and Lester, 2017), but they do tend to make greater foreign acquisitions which are value destroying (Hanlon, Lester, and Verdi, 2015). They also increased their foreign cash more rapidly when a repatriation holiday became more likely (De Simone, Piotroski, and Tomy, 2017). These facts are all consistent with foreign cash being a poor source of precautionary savings, which is what we show.
} 
is no reduction in domestic cash of MNCs as the effective tax rate falls (see Table 3, column IV).

The coefficient estimate in column VI implies that lowering the effective tax rate from $35 \%$ to $30 \%$ (approximately the standard deviation from Table 2) will increase the foreign cash to assets ratio by 3.7 percentage points. This is an increase of $42 \%$ relative to the mean $(3.7 / 8.9)$. Foley et al. (2007) also find a statistically significant relationship between the cost of repatriating and the level of foreign cash (see their Table 5, column 1). A one standard deviation rise in the cost of repatriation (lower foreign tax rates) increases the foreign cash to asset ratio by $12 \%$ (see Foley et al. (2007), page 595). The magnitude of the effect we document is $3.5 \mathrm{x}$ larger, and is even larger when we look at the actual change in the foreign cash to assets ratios. In their results, this ratio rises by $0.1 \%$ (i.e. 10 basis points from $0.71 \%$ to $0.81 \%$ ); our regressions imply an increase of 3.7 percentage points or $37 \mathrm{x}$ larger (See Appendix I for a comparison of the tax variables used in our paper and Foley and the calculation of the magnitude of the effects).

Why would the sensitivity of foreign cash to foreign tax rates be so much higher in our sample? We think the answer is the different sample periods. Foley et al. (2007) use the BEA benchmark surveys from 1982, 1989, 1994, and 1999 to measure foreign cash. We create an annual panel using both the BEA's benchmark survey and the annual surveys, spanning 1998 to $2008 .{ }^{21}$ The two sample periods have little overlap. At the beginning of our sample and during the Foley sample, the average foreign tax rate and the U.S. corporate tax rate are very similar (see Figure 3

\footnotetext{
${ }^{21}$ In the annual surveys, we must estimate marketable securities by subtracting an estimate of accounts receivable from other current assets (see equation 2). Total foreign cash is higher in the benchmark years (1990 and 2004) relative to surrounding years (see Figure 2). One interpretation is that we are under-estimating the level of foreign cash because we are subtracting off too high a number for accounts receivable in the non-benchmark years. The benchmark survey also includes long-term marketable securities that may also account for the higher values in these years. The time dummies in the regression will absorb this effect if it effects all firms the same. To verify that our estimation approach does not change our results, we re-estimated the main regressions in Table 3 using only the benchmark years of 1999 and 2004 (see Supplementary Table 3). Although the sample size shrinks and we thus lose some statistical significance, the basic results change very little. The coefficient on the effective tax rate shrinks from -0.743 to -0.663 and the tstatistic is still greater than 7.2 (column V). The coefficients on the precautionary savings variables are similar in most cases.
} 
and Figure 4-C in Graham and Leary (2017)). However, during the course of our sample period, average foreign tax rates fall significantly. When average foreign tax rates are equal to U.S. tax rates, the tax benefits for shifting income to foreign subsidiaries are minimal, and thus less cash is trapped abroad. Over time, as foreign tax rates have come down, the incentive to move income abroad has increased. Figure 2 shows that during this period when U.S. and foreign corporate tax rates diverged, foreign cash grew much faster.

The enactment of the "check-the-box" regulation also facilitated the ability of firms to shift income overseas. This occurred in 1997, near the end of the Foley sample and just before the beginning of ours. The U.S. Treasury enacted "check-the-box" (CTB) regulations to simplify tax policy by allowing firms to self-identify subsidiaries for tax purposes (Albertus, 2016). What followed was the proliferation of hybrid entities where a subsidiary could be considered a "disregarded entity" by U.S. tax laws but be treated as a corporation in the foreign jurisdiction. Normally, financial payments between a parent firm and its foreign subsidiary would have tax implications, as the U.S. tax code does not defer taxation of "passive income" or "Subpart F income." Check-the-box regulations allowed firms to treat such payments as internal transfers and not subject to U.S. taxation, encouraging the creation of these overseas hybrid entities. CTB was enacted in January of 1997 but was quickly considered for repeal. In April 1998, the repeal idea was dropped by the Senate Finance Committee and the regulation was perceived as enduring (Drawbaugh and Sullivan, 2013). Blouin and Krull (2014) document a growth of subsidiaries in tax haven countries and a growth of intercompany transfers following passage of CTB 
regulations. ${ }^{22}$ Together, the incentive and ability to transfer price has made the role of foreign taxes significantly more important over time.

\section{The Rise in Corporate Cash: Precautionary Savings versus Tax Effects}

Our regression results are based on a panel data set, and so the coefficients are estimated from both cross-sectional and time-series variation. Firms with poorer access to capital markets may hold more cash (cross-sectional variation) or, as firm's access to the capital markets improves (e.g. they get larger or investment risks declines), they may hold less cash (time-series variation). We can use our coefficient estimates and the change in the independent variables to document how much of the change in the cash to assets ratio over our sample period is due to changes in the precautionary versus tax motivations. The average domestic cash to assets ratio for all firms rises by 0.7 percentage points over our sample period. The change in the precautionary savings variables (everything except the tax rates and the time dummies) implies a decline of 1.6 percentage points. The declining tax rate has no effect on domestic cash. The time dummies, which pick up intertemporal changes in domestic cash that is uncorrelated with the independent variables, imply an increase of $2.3 \%$. Thus, the included precautionary savings variables do not explain the rise in domestic cash. ${ }^{23}$

The foreign cash to assets ratio of MNCs rises from 6.8 to 12.0 percentage points, an increase of 5.2 percentage point. This increase is explained almost entirely by the drop in the

\footnotetext{
${ }^{22}$ In their Figure 1, Blouin and Krull (2014) show that the average number of subsidiaries in tax haven rose from two in 1983 to three in 1998. It then rises to five by 2008. Klassen and Laplante (2012) find that firms more actively shift income out of the U.S. as the regulatory costs fell and the firms learned how to shift income.

${ }^{23}$ These calculations do not include the effect of changes in the standard deviation of cash flows over our sample period. The coefficient on the standard deviation of cash flows is statistically significant in explaining the domestic cash held by MNCs (Table 3, column V). If we included this variable in the domestic cash regression (Table 3, column III), the rise in the standard deviation of cash flows would imply an increase in the domestic cash to asset ratio of only 0.09 percentage points for all firms $(0.0009=0.024[0.158-0.121]$, results available from the authors $)$ and 0.27 percentage points for MNCs $(0.169[0.058-0.042])$. The standard deviation of cash flow is important in explaining the cross sectional variation in domestic cash, but does not explain a significant increase in domestic cash over our sample period. We thank the referee for recommending this calculation.
} 
effective tax rate. The decline in the effective tax rate implies an increase in the foreign cash to asset ratio of 4.1 percentage points. The time dummies imply an increase of only 0.1 percentage points.

In these regressions, we document the factors that lead to a rise in the firm's cash to asset ratio. The increases we document here are smaller than the increases in total cash that we graphed in Figure 2. The domestic cash to asset ratio for all firms rises by $4 \%$ or 0.7 percentage points from $19.4 \%$ to $20.1 \%$, while total domestic cash (dollars) rises by $80 \%$ in Figure 2 (all firms). The change in total (dollar) cash arises from three sources: the change in a firm's cash to asset ratio (which we document in Table 3), changes in firm size (book value of assets), and changes in the number of firms. To control for changes in the number of firms, we recalculated Figure 2 and the regressions using a balance sample (i.e. the firms appear in Compustat all 11 years, results available from the authors). In this case, total cash rises by $70 \%$ (versus $80 \%$ in the full sample) and the domestic cash to asset ratio falls by 0.009 (opposed to a rise of 0.007 in the full sample). ${ }^{24}$ Thus the increase in total domestic cash that we see in Figure 2 is driven completely by firms becoming larger, opposed to firms saving more cash.

The results for foreign cash tell a different story. The foreign cash to asset ratio rises by $77 \%$ or 5.2 percentage points from $6.8 \%$ to $12.0 \%$, while the total foreign cash of MNCS (in dollars) rises by $440 \%$ in Figure 2. As with domestic cash, we recalculated Figure 2 and the regression using a balanced sample. In the balanced sample, total foreign cash rises by $580 \%$ (versus $440 \%$ in the full sample) and the cash to asset ratios rises by 5.4 percentage points (versus 5.2 percentage points in the full sample). Thus, the rise in foreign cash comes from a slight increase in the number of MNCs ( 8 percent), an increase in firm size, but also a significant increase in the

\footnotetext{
${ }^{24}$ The number of domestic firms falls over our sample period by $35 \%$.
} 
foreign cash that firms choose to hold controlling for size. Since our interest is in a firm's decision of how much cash to hold and how this has changed, not in explaining changes in firm size, our regressions use the cash to asset ratio as the dependent variable. ${ }^{25}$

\section{Income Shifting and Intangible Assets: The Mechanism behind Cash Accumulation?}

\section{A. Transfer Pricing as the Mechanism}

Holding cash abroad may reduce financial flexibility (domestic cash generally is a better store of precautionary savings), but it can have significant tax benefits. We next explore which firms choose to build up foreign cash stockpiles and demonstrate how such firms actively minimize taxes. Firms don't usually transfer cash into low tax jurisdictions, but they may relocate profit and cash flow generating assets into lower taxed subsidiaries. Thus, transfer pricing - how within-firm sales are priced - is an important element in the movement of earnings to low tax jurisdiction subsidiaries (Grubert and Mutti, 1991). Starbucks, for example, was investigated by European Commission regulators for whether "Dutch authorities allowed Starbucks to use unfair methods to shrink its taxable income, including paying a royalty to a partnership in Britain, Alki, for a recipe for coffee-roasting" (Kanter, 2014). Underpinning transfer pricing is the nature of the intellectual property of the firm. Not only is it easier to transfer intellectual property to low tax jurisdictions than to transfer physical capital, it is also easier to avoid charges of tax avoidance when income arises from more difficult to value assets such as patents and technology (Grubert, 2003, Levin and McCain, 2013, De Simone, Huang, and Krull, 2017, Guvenen et al., 2018). Thus, firms with more unique assets have greater ability to lower their effective tax rates by transferring income to

\footnotetext{
${ }^{25}$ Alternatively, we could have run our regression with the log of cash as the dependent variable. In this specification, a lower effective tax rate still leads to higher foreign cash balances, but so does having a debt rating or having greater sales (results available from authors). This is the challenge with interpreting a regression whose dependent variable is not scaled by firm size. Any variable which is positively correlated with firm size will predict higher cash holdings.
} 
low tax jurisdictions. Although this is a plausible channel that could explain the rise in foreign cash, what is missing is empirical evidence making the connection. ${ }^{26}$

\section{B. Empirical Role of Related Sales}

To empirically document the role of transfer pricing in the rise of foreign cash, we first calculate the portion of a firm's sales that it deems "related" or "affiliated" (related sales). In the BEA data, firms report the subsidiary's revenue arising from sales to the other subsidiaries of the firm or to its parent. We sum the related sales across all foreign subsidiaries of the firms and express this amount as a percentage of the firm's total revenue. We hypothesize that, if transfer pricing is a mechanism that facilitates the movement of earnings to low tax jurisdictions, then the firms with high levels of related sales and low effective tax rates will accumulate more cash abroad. The analysis is presented in Table 4.

While higher related sales do not increase domestic cash (see Table 4, column I) for MNCs, both the effective tax rate and related sales are important determinants of foreign cash holdings. The coefficient on the effective tax rate is negative, the coefficient on related party sales is positive, and both are statistically different from zero (Table 4, column II, p-value $<0.001$ ). The coefficient on the cross product (tax rate multiplied by related sales) is negative but not statistically different from zero. While low tax rates themselves are important in explaining large foreign cash positions, this effect is enhanced by low tax-rate firms' abilities to move income around within the firm. Firms with greater ability to move income to low tax jurisdictions (through related party sales) have more opportunity to lower their taxes and are the ones with the largest foreign cash balances. Over our sample period, related sales have grown significantly, consistent with their role in the

\footnotetext{
${ }^{26}$ Foley et al. (2007) suggest the transfer-pricing channel could be important in explaining the rise in cash, but their paper notes a lack of empirical documentation citing only anecdotal evidence. "Anecdotal evidence suggests that technology-intensive firms can shift income to low tax jurisdictions more easily than other types of firms..."
} 
rise of foreign cash. The average of the ratio of related sales originating from all the subsidiaries in a given country divided by the GDP of the country is graphed in Figure 4 - Panel A. Related sales start to grow faster than the country's economy beginning in 1999 (the second year of our sample). This corresponds to timing of check-the-box regulation, which facilitated income shifting. If we divide the sample into countries that are classified as tax havens and those that are not, the growth in related sales (relative to the economy) is concentrated exclusively in the tax haven countries (see Figure 4 - Panel B).

\section{Empirical Role of Intangible Assets}

These results still do not explain why all firms don't engage in such related party sales to lower their corporate income tax liability. There must be some restriction on firms' ability to place subsidiaries in low tax jurisdictions and/or use related party sales to lower taxes. Intangible assets are easier to reallocate to low tax jurisdiction countries than are economic values arising from physical capital (e.g., manufacturing, mining, timber, etc., see De Simone, Mills, and Stomberg (2017). To further explore this channel, we divide the sample into those firms engaged in significant intellectual property development, as measured by disclosing material amounts of R\&D spending (non-zero and non-missing) and those firms without material R\&D spending (see Table 4, columns III and IV).

Intellectual property matters. Among firms with no R\&D expenditure, lower tax rates do lead to higher foreign cash balances, but related sales have no effect (the coefficient is positive but small and statistically indistinguishable from zero). The effect of related sales on foreign cash holdings appears only among firms with R\&D expenditures (column IV) ${ }^{27}$ When related sales are

\footnotetext{
${ }^{27}$ Firms without intangible assets do have supply changes that reach across their different foreign subsidiaries (i.e. positive related sales), although both the level and increase in their related sales is much smaller. The related sales of firms without R\&D increase from 5.1 to $5.3 \%$ over our sample period, while the related sales for firms with positive R\&D increase from 12.3 to $19.7 \%$. As we discussed above, it is more difficult to set transfer prices which deviate
} 
zero, the effect of taxes on foreign cash holdings is very similar for firms with and without R\&D

(compare the coefficient on the effective tax rate in columns III and IV). Not only do increases in related sales increase foreign cash holdings directly for firms with R\&D expenditure, but they also increase the effect of lower foreign taxes on foreign cash holdings (the coefficient on the cross product is negative, economically large, and statistically significant) ${ }^{28}$ For example, lowering the effective tax rate from $35 \%$ to $30 \%$ and increasing related sales by $22.5 \%$ (the interquartile range) increases the cash to net book assets by 7.4 percentage points. ${ }^{29}$ This is large relative to the mean and standard deviation of foreign cash from Table $2(8.9 \%$ and $14.7 \%) .{ }^{30}$

Using the coefficient estimates, we can measure how much of the rise in the foreign cash to asset ratio over our sample period is due to precautionary savings versus tax effects. For firms with positive R\&D (Table 4 - column IV), the foreign cash asset ratio rises by 6.9 percentage points or $87 \%$ (from 7.9 to $14.8 \%$ ). A majority of the rise is due to changes in the tax variables. The effective tax rates falls from 35 to $29 \%$ and related sales rises from 12 to $20 \%$, and this leads to a 4.6 percentage point increase in foreign cash to assets. Changes in precautionary savings lead to a 0.6 percentage point increase. The remaining rise is absorbed by the time dummies.

from economic value when assets are tangible. For example if one subsidiary extracts and sells copper to another subsidiary which manufactures copper pipe, there is an arms-length market price of copper which tax authorities can use as a comparison. In addition, where the copper is extracted and where the pipe is manufactured is more easily observable. This is why we find related sales are mechanism to transfer income to low tax countries and thus lead to a rise in foreign cash only in firms with positive $R \& D$.

${ }^{28}$ When we estimate these regressions using only the two benchmark years, the results for the set of firms with R\&D are similar (see Supplementary Table 4, column IV). The coefficient on the effective tax rate shrinks but is still statistically significant. Both the related sales and cross product coefficients increase and are statistically significant.

${ }^{29}$ For the MNCs with zero R\&D (column III), lowering the tax rate from 35\% to 30\% raises the foreign cash to net book asset ratio by only 2.0 percentage points.

${ }^{30} \mathrm{R} \& \mathrm{D}$ expenditures have no direct effect on foreign cash. The coefficient on R\&D is small in magnitude (Table 4, column IV). In our results, $R \& D$ expenditure has a binary effect on foreign cash. It measures a firm's ability to use transfer pricing. This is very different from the findings of Foley et al. (2007). They find a positive and statistically significant effect of $R \& D$ on foreign cash that is almost as big as the coefficient in the domestic cash regression (see their Table 5 and 6). This is what we would expect when foreign tax rates do not differ significantly from U.S. rates. In this case, foreign and domestic cash are equally valuable stores of precautionary savings. When foreign tax rates fall significantly below U.S. rates, however, the value of foreign cash as a source of precautionary savings declines. This is why we find a small coefficient on $R \& D$ expenditure and instead $R \& D$ denotes the ability to use transfer pricing during our sample period. 
As we saw in Figure 2, the rise in foreign cash of MNCs has been much greater than the rise of domestic cash (in either domestic firms or MNCs). Our empirical results document the role of intellectual property and transfer pricing in moving earnings from high tax jurisdictions to low tax jurisdictions, resulting in significant amounts of trapped cash. To see their role, we graph total foreign cash held by MNCs that report positive R\&D and positive related sales versus all other MNCs in Figure $5 .{ }^{31}$ It is clear that the dramatic growth in foreign cash has been concentrated in the firms who can and do use transfer pricing to move income to low tax jurisdictions. This is true if we examine total foreign cash (Figure 5 - Panel A) or the foreign cash to asset ratio (see Figure 5 - Panel B). Over our sample period, there has been very little increase in the foreign cash held by firms that do not have positive R\&D or positive related sales. In fact, $92 \%$ of the increase in foreign cash that we observed in Figure 2 occurs in firms that have both positive R\&D and positive related sales. As the rise in cash is concentrated in foreign cash and the rise in foreign cash is concentrated in a subset of firms, we need to focus on these firms. ${ }^{32}$

While the statutory corporate tax rate measures the marginal tax rate specified in the tax code, it may not fully capture the marginal tax rates that firms actually face on their foreign income. For example, the country of Luxembourg was known to write firm-specific special agreements that dramatically reduced the tax rate - often to near zero (Bowers, 2014; Karnitschnig and Van Dallen, 2014). To determine how important this is to our results, we replaced our effective tax rate variable with a dummy variable that is equal to one for firm-years in which the firm has at least

\footnotetext{
${ }^{31}$ We also graph total cash for MNCS with positive versus zero R\&D in Supplementary Figure 1 and for MNCs with positive versus zero related sales in Supplementary Figure 2.

${ }^{32} \mathrm{We}$ can also split the sample based on measures of precautionary savings to see if the rise in foreign cash is more pronounced in firms with stronger precautionary demand for cash. When we split the sample based on firms' market fluidity (see Supplementary Table 2), we see no difference in the rise in foreign cash. MNCs with above median value of the market-fluidity risk measure see their foreign cash rise by $5.5 \mathrm{x}$ versus $5.2 \mathrm{x}$ for firms with values of market fluidity below the median.
} 
one subsidiary in a tax haven country (see Dyreng and Lindsey, 2009). ${ }^{33}$ The tax haven variable has the potential advantage of picking up variation in the marginal tax rate not captured by the statutory rate, while the effective tax rate variable has the potential to capture tax rate changes across firms and over time.

The results using the tax haven dummy are broadly similar to earlier results. Firms that have a subsidiary in a tax haven have a foreign cash to asset ratio that is 4.3 percentage points higher (see Table 4, column VI). As before, increases in related sales raise foreign cash by a statistically significant amount. The coefficient on related sales has not changed for firms with zero R\&D (compare the coefficient in columns III and VII). It is now statistically significant but still smaller than for firms with positive R\&D. The cross product is large and statistically significant. The economic magnitude of the tax variables is slightly larger in this specification. Changing from zero to a positive number of subsidiaries in a tax haven and increasing related sales by $22.5 \%$ (the interquartile range) increases the foreign cash to net book assets by 11.2 percentage points for firms with positive R\&D (see Table 4, column VIII).

Foley et al. (2007) also examine the joint effect of R\&D and foreign taxes on firms' foreign cash holdings, but their results are very different. They regress the log of the foreign cash to assets ratio on the foreign tax rate (country tax) and the foreign tax rate interacted with the R\&D to assets ratio (see their Table 8, column 3). The coefficient on the country tax rate is negative. The lower the foreign tax rate, the more foreign cash in the subsidiary. This makes sense. However, this coefficient measures the effect of the foreign tax rate for firms whose R\&D expenditures are zero. The interaction coefficient is positive and large. Thus for firms that invest in $\mathrm{R} \& \mathrm{D}$, the coefficient

\footnotetext{
${ }^{33}$ Countries are identified as tax havens by the nonprofit Global Policy Forum. While Table 1 of Dyreng and Lindsey (2009) lists 38 countries, many locations (such as Andorra, Botswana, and Vanuatu) do not have subsidiaries of U.S. multinationals. Our sample includes 20 countries that are classified as tax havens (e.g., Ireland, Luxembourg, and Panama).
} 
on the foreign tax rate turns positive. ${ }^{34}$ That implies that for high R\&D firms, where transferpricing opportunities should be the largest, foreign cash actually declines as tax rates decline. This does not make sense. These results may arise due to the small difference in foreign and U.S. tax rates during their sample period and not controlling for related sales.

\section{Changes in Cash}

The regressions run thus far have been in levels. The regressions are specified this way, in part, since the precautionary savings explanation is a story about levels. Firms with more limited access to the capital markets, and which face greater investment risk, maintain a higher average level of cash. The tax explanation is a story about both levels and changes. First, as tax rates have fallen in many foreign countries relative to the United States (see Figure 3), the incentive to earn income in foreign subsidiaries has risen as well; as a result, cash builds up in the firm's foreign subsidiaries (Dobridge and Landefeld, 2017). This is a story about the level of foreign cash. However, even if the difference between U.S. and foreign tax rates does not change, the level of foreign cash may still rise. When the foreign tax rate is less than the U.S. tax rate, firms have an incentive to earn income in low tax foreign jurisdictions each and every year and thus add to their stockpile of foreign cash, even if tax rates do not change.

As a test of this alternative specification, we reran the regression from column IV using the change in foreign cash divided by assets as the dependent variable (see Table 4, column IX). ${ }^{35}$

\footnotetext{
34 The coefficient on foreign taxes is positive in column 3 for firms with an R\&D/Asset ratio above 0.0243 $(19.3482 * 0.0243-0.4709=0)$. The mean $\mathrm{R} \& \mathrm{D} /$ Asset ratio is 0.0262 , the median is zero, and the standard deviation is 0.0538 .

${ }^{35}$ A third way to estimate the model is to run the regression in levels but include firm dummies. Since the dummies absorb the cross sectional variation, the coefficients are now estimated from deviations of each year's value from the firm specific means, opposed to the overall means. Related sales still has no direct effect for firms with zero R\&D, and declines in the effective tax increase firm's cash holdings as before (see Table 5, column II). The cross product coefficient is now positive and statistically significant, but the coefficient on the effective tax rate remains negative for reasonable values of related sales. The results for firms with positive R\&D are reported in Table 5, column III. These firms hold more foreign cash as their tax rates fall, but unlike the model without firm dummies, only if they
} 
Although the coefficients appear to be smaller, the implications are the same. MNCs that face lower foreign tax rates and have higher related sales accumulate foreign cash at a faster rate, and the two coefficients are statistically significant (the cross product is not). Lowering the effective tax rate from $35 \%$ to $30 \%$ and increasing related sales by $22.5 \%$ (the interquartile range) increases the dependent variable by 0.8 percentage points. This is smaller than the 7.4 percentage point increase we found in column IV, but the magnitudes are not directly comparable. This change is the increase in foreign cash that would occur each year over our 11-year sample period in response to the lower tax rate and the higher related sales. ${ }^{36}$

\section{E. The Role of Income Shifting}

The rise in foreign cash that we document arises from three broad factors: the growth of international business activity, the decline in foreign tax rates, and the ability of firms to shift their income into low tax jurisdictions. We return to the question of how much of the rise in foreign cash is due to the faster growth of foreign operations in the next section. As foreign tax rates have fallen over our sample period, the cost of repatriation has risen. As the regressions show, this has led to a rise in foreign cash. This is a passive response; cash will rise even if income is not shifted. However, as the foreign tax rate falls below the U.S. rate, firm's incentive to shift income into low tax jurisdictions increases. The fact that most of the increase in foreign cash is in firms with positive R\&D and related sales is evidence of income shifting, but we can look at this question more directly. The effective tax rate has fallen over our sample period in part because of the decline in foreign tax rates. It has also declined because firms are earning an increasing portion of their

have positive related sales. This is consistent with Figure 5 where the rise in cash is predominantly in firms with related sales and positive $R \& D$.

${ }^{36} \mathrm{We}$ also ran the domestic cash regressions using changes. The coefficient on the precautionary savings variables are smaller in magnitude and less statistically significant. This is consistent with the precautionary story explaining cash levels, not changes. 
income outside the United States. The mean fraction of income earned abroad has risen from $38 \%$ to $53 \%$ over our sample (see Figure 6 ).

To understand the importance of each of these sources of variation, we bifurcate the effective tax rate variable into its two components: the foreign tax rates and the fraction of the firm's income (EBIT) that is earned in foreign jurisdictions. Decreasing the foreign tax rate (the average tax rate the firm faces on income across its foreign subsidiaries) increases the amount of foreign cash which MNCs hold, but has no statistically significant effect on domestic cash (see Table 6). We also see that income is sticky; cash tends to be held where it is earned. The more income that is earned in the United States, the more domestic cash the firm has (Table 6, column I). The more income earned in foreign subsidiaries, the more foreign cash the firm holds (column II). Foreign income is significantly stickier than domestic income; the coefficient on U.S. income is three times larger in the foreign cash regressions (-0.129 versus 0.042$)$. This difference is evidence of the asymmetry introduced by the tax code. The increase in foreign cash appears to be due to both the reduction in foreign tax rates and the movement of income abroad.

Declines in the effective tax rate, combined with the growth of related sales, explain most of the increase in foreign cash (see Table 4). We know that the effective tax rate falls over time due to a decline in the foreign tax rates and a shifting of income to or across foreign jurisdictions. We can show the role of related sales by graphing the average effective tax rate over our sample for MNCs with positive versus zero related sales (see Figure 7). There are several things to note. First, the average effective tax rate in the two samples is the same (and equal to 35\%) in 1998. Prior to divergence in foreign tax rates and the effect of CTB, the two groups look the same. Over the next decade, as foreign tax rates have fallen, the effective tax rates of both sets of firms have fallen. However, the effective tax rates have fallen faster for the firms with positive related sales: 
a drop of 6.9 percentage points for firms with related sales (solid line) versus 3.2 for firms with no related sales (dotted line). To document how much of the fall in the effective tax rates is from lower foreign tax rates versus shifting income to low tax jurisdictions, we calculated a static version of our effective tax rate variable. Instead of the fraction of income earned in each subsidiary and the U.S. (the weights) changing each year, we fixed the weights at their 1998 values (or the first year the firm enters the sample, see equation 1). Changes in the static effective tax rate measure only changes in foreign tax rates in countries where the subsidiaries were initially located. For firms with no related sales the static and (dynamic) effective tax rate are the same (compare the dashed line to the triangles in Figure 7). These firms do not shift income toward low tax jurisdictions. For firms with positive related sales (compare the solid line to the squares in Figure 7), we see evidence of significant movement of income to low tax jurisdictions. The effective tax rate falls by almost twice as much when income shifting is included (a decline of 6.9 percentage points in the effective tax rate versus a fall of 3.9 in the static tax rate). Interestingly, the divergence between the dynamic and static effective tax rate (i.e. income shifting) does not begin until a few

years after the CTB regulations become effective, as there is a lag between the relocation of intellectual property into low tax subsidiaries and the resulting accumulation of cash.

\section{Subsidiary Level Results}

\section{A. Tax Based Reasons for Shifting Income}

The analysis thus far has treated each firm's foreign subsidiaries as a single entity. In reality, firms have foreign subsidiaries in many different countries with potentially very different tax rates, and our data allows us to observe the cash and operating activity in each of the firm's subsidiaries. The decision of where to invest and earn income is driven in part by where business opportunities exist, which is why we find that the fraction of cash and the fraction of sales 
generated in the foreign countries were similar in 1998 (see Table 1). However, it is also driven by differential taxation. Not only do firms have a tax incentive to move income out of the United States and into foreign subsidiaries with low tax rates, but they also have an incentive to move income out of foreign subsidiaries with high tax rates and into foreign subsidiaries with lower tax rates.

In Figure 7, we saw that firms with related sales shifted income to low tax countries. In Table 7, we explicitly examine this question. To document how foreign tax rates drive where firms earn income, we calculate the fraction of a firm's income that it earned in each of its foreign subsidiaries in both 2008 and 1998 and then calculated the difference. For subsidiaries that are added after 1998, we set this percentage to zero for 1998. For subsidiaries that are closed before 2008 , we set this percentage equal to zero in 2008. Thus, the change in the percent of income earned in each subsidiary includes not only changes in the level of the income earned in each foreign subsidiary but also the decision to open and close subsidiaries. We then regress the change in the foreign income percentage on the change in the foreign tax rate the firm faced in each country. Oddly, declines in the foreign tax rate seem to have no effect on changes in the fraction of income a firm earns in a subsidiary/country (see Table 7, column I).

There is a potential problem with this specification. Some countries already had tax rates in 1998 that were lower than the U.S. rate. With the relaxation of regulations governing the shifting of income (see prior discussion of "check-the-box" regulations), firms may have shifted income to a country that had a low tax rate relative to the U.S. rate even if the country did not lower their tax rate further. We saw in Figure 7 that income shifting appears to begin a few years after finalization of the CTB rules. To account for the initial (1998) difference in tax rates, we include the minimum of the foreign tax rate in 1998 minus $35 \%$ and 0 . This measures how much lower the 
foreign tax rate is at the beginning of our sample. Firms increase the fraction of income earned in a country between 1998 and 2008 when the foreign tax rate was initially further below the U.S. rate (see Table 7, column II). With this additional control, we also find a statistically significant, but smaller, coefficient on the change in the tax rate. We also find that the related sales originating in a subsidiary increase as the tax rate in the country declines, controlling for total sales from the subsidiary (see Supplementary Table 5). Thus, over our sample period, we find that firms shift income toward foreign countries that initially had lower tax rates, and the effect is stronger if the foreign country lowered its tax rates.

\section{B. Subsidiary Level Cash Regressions}

Given our data on the cash levels in each of the firm's foreign subsidiaries, we are able to run the regressions from Table 4 using subsidiary-level instead of firm-level observations. ${ }^{37}$ The number of observation rises by a factor of over 10, from 7,627 in Table 4 (column IV) to 78,165 in Table 8 since firms have multiple foreign subsidiaries. Table 8 contains observations only on firms with positive R\&D. The dependent variable is the subsidiaries' cash divided by the firm's net book value of assets. ${ }^{38}$ The results are similar to what we found at the firm level, with a few exceptions. The lower the country tax rate, the more cash a firm holds in that subsidiary. The higher the fraction of subsidiary sales to other subsidiaries or to the parent (related sales); the more cash is held in the subsidiary. The cross product is negative and statistically significant. We find

\footnotetext{
${ }^{37}$ The dataset has limited information about the financials of each subsidiary. We included the PPE to asset ratio and the R\&D to sales ratio measured at the subsidiary level in Table 8 . These are measures of precautionary savings used in the literature and in the prior regressions (see Table 4). The coefficient on PPE is positive, not negative as implied by the precautionary savings explanation and found in Table 4 . The coefficient on R\&D is positive and statistically significant, but the magnitude is a fraction of what we found for domestic cash in Table 4 (i.e. 0.007 in Table 8, column III versus 0.279 in Table 4, column I). The coefficient on R\&D is negative and not statistically significant in the foreign cash regression (Table 4, column II).

${ }^{38}$ We are interested in the firm's decision of how much cash a firm has and where to hold it. Thus, we continue to use the firm's asset value in the denominator instead of the subsidiaries asset value. We do this so that the coefficients are comparable across tables. In addition, as some of the subsidiaries have low asset values and sales (see Table 2); large values for the dependent variable could be driven by low tangible assets rather than large cash holdings.
} 
the same results whether we include no dummy variables (Table 8, column I), firm dummies (Table 8, column II), or firm-year dummies (Table 8 , column III).${ }^{39}$ When we include a separate dummy variable for each firm-year combination, the tax coefficient is estimated from variation in the tax rate across different subsidiaries for a given firm and year. ${ }^{40}$

The rise in cash held in foreign subsidiaries could be a simple consequence of an increasing amount of business activity taking place in foreign subsidiaries. The regressions in columns $\mathrm{V}-$ VIII help distinguish this effect versus the tax effects. We include the fraction of a firm's sales that originate in the subsidiary, as well as the interaction with the foreign tax rate. First notice that increasing a subsidiary's sales over time or relative to the firm's other subsidiaries raises the amount of cash held in the subsidiary, but the magnitude is tiny compared to the effect of related sales. The coefficient on related sales is $31 \mathrm{x}$ larger $(0.472$ versus 0.015 , see Table 8 , column VII). The interaction of subsidiary sales and the foreign tax rate is tiny and statistically insignificant. More importantly, the coefficients on the related sales and the foreign tax rate variables does not change significantly when we control for subsidiary sales. It isn't the magnitude of business activity (sales) but to whom the sales are made (related parties) and low tax rates that explain the rise in foreign cash. ${ }^{41}$

\footnotetext{
${ }^{39}$ When we include country dummies, the coefficient on the foreign tax rate becomes zero, but the coefficient on the interaction between the foreign tax rates and related sales is large and statistically significant. This means the reduction in foreign tax rates only effected firms with positive related sales.

${ }^{40}$ When we run these regressions for firms with zero R\&D, the magnitude of the coefficient on the foreign tax rate is similar: -0.023 for firms with positive R\&D (see Table 8, column III) versus -0.030 for firms with zero R\&D (see Table 9, column III). The coefficient on relate sales is smaller and only marginally statistically significant. The coefficient on the cross produce is much smaller and never statistically significant. As we found in Table 4, lower foreign tax rates increase the cash held in the foreign subsidiaries for all firms, but the effect of relates sales (and relates sales interacted with the foreign tax rate) is there only for firms with positive R\&D. These re the firms which can use transfer pricing to move income into low tax subsidiaries.

${ }^{41}$ We replaced the effective tax rate by a dummy variable for whether the firm is a tax haven in Supplementary Table 6 the results are similar. Firms accumulate more cash in subsidiaries that reside in tax havens and this effect is accentuated the more related sales that originate from that subsidiary. Controlling for total subsidiary sale does not change this intuition.
} 
The magnitude of the tax effect appears to be smaller than we find in Table 4. This is because the dependent variable is foreign cash in one subsidiary, not all of the subsidiaries (scaled by firm assets). The tax effects are large relative to the cash held in a single subsidiary. Based on the coefficients in Table 8 (column VII) lowering the foreign tax rate by one standard deviation (0.092) and increasing related sales by one standard deviation (0.037) increases the subsidiary cash to net book assets by 1.1 percentage points. This is large relative to both the mean $(1.2 \%)$ and the standard deviation (4.1\%) of the dependent variable.

\section{Implications for Firm Behavior Following Tax Reform}

Our empirical results may also cast light on firms' responses to tax changes included in the Tax Cuts and Jobs Act of 2017 (passed in December of 2017). There are three potentially relevant changes. First, the reform eliminated the incremental tax firms pay when they repatriate income from their foreign subsidiary although the law did include a one-time tax on the stock of unrepatriated income. Going forward repatriation will no longer trigger additional taxes and thus the tax motivation for delaying repatriation and keeping cash in a foreign subsidiary has been eliminated. We are back to firms having a single, universally accessible checking account.

Our results show that firms' objective was not to stockpile cash abroad. This was an unintended consequence of their desire to lower the present value of taxes by shifting income to low tax jurisdictions. Our results demonstrate that this effect is large, accelerates after 1998 due to regulatory change and a reduction in foreign tax rates relative to US rates, and is concentrated in firms whose operation depends upon intangible assets (i.e. firms with material R\&D expenditures). The reduction in the top marginal corporate tax rate from $35 \%$ to $21 \%$ should significantly reduce firms' incentive to move income abroad, but not to zero. A number of countries still have corporate 
tax rates less than $21 \%$, and many countries may lower theirs tax rates even further, so it is an empirical question as to how small the difference in tax rates must be to dampen this incentive.

The third relevant change in the law was the addition of new provisions that are designed to constrain firms' incentive, and thus willingness, to shift income across countries. With the Tax Cuts and Jobs Act of 2017 (TCJA), the US moved to a quasi-territorial tax system where the income generated in foreign subsidiaries of US MNCs would not be taxed, with some exceptions. The base erosion and anti-abuse tax (BEAT) imposes a minimum tax on US tax payers, starting at 5 percent in 2018 and rising to $12.5 \%$ in 2026 (Huynh, Quinn, Hill, 2018). Payments to affiliated foreign entities (e.g. a foreign parent) must be added back when calculating taxable income under BEAT. Payment of interest, insurance premiums, or royalty payment on intangible assets are examples of these base erosion payments (Harris and Looney, 2018). The global intangible lowtaxed income (GILTI) taxes the income US MNC's foreign subsidiaries on any income greater than $10 \%$ of tangible assets (Bloomberg BNA, 2018). Thus, foreign subsidiaries with predominantly intangible assets could find that some of their income is taxed in the US, whether it is repatriated or not.

As we have documented, the set of firms whose operation relies predominantly upon intangible assets have increased the amount of income they earn in foreign subsidiaries in low tax countries. The lower US tax rate and the addition of the BEAT and GILTI taxes may dampen these income-shifting incentives. We leave this to future research to document by how much and the resulting impact on the quantity and location of firm cash.

\section{Conclusions}

What explains the dramatic rise in corporate cash? We confirm that precautionary motives are an important factor in a firm's decision to hold cash. However, precautionary motives only 
explain the cross-sectional variation in domestic cash. They are not important in explaining the level of foreign cash or the rise in total cash.

To explain the rise in total cash, we focus on the rise in foreign cash. A majority of the rise in total cash and $85 \%$ of the rise in the cash held by MNCs is due to a rise in MNCs' foreign cash (see Figure 2). We find that precautionary motivations explain none of the rise in foreign cash, which is not surprising since foreign cash is a poor source of precautionary savings when repatriation is costly. The rise in foreign cash is instead driven by tax factors. As the incentive and ability of firms to earn income in, or shift income to, low tax foreign jurisdictions increased, the rise in foreign cash followed. Starting at the beginning of our sample (1998), average foreign tax rates began to fall below U.S. tax rates. At about the same time, check-the-box (CTB) regulations came into effect and allowed firms greater latitude in shifting income into foreign countries. We document that the rise in related sales does not begin until after CTB regulations become effective. We find that a combination of lower foreign tax rates and increasing levels of inter-company sales (related sales) explains most of the rise in foreign cash. Not all firms, however, are able to shift income abroad. We find lower foreign tax rates lead to higher foreign cash for all firms, but the effect of related sales is only important for firms with intangible assets, which we measure as positive R\&D expenditures. Ninety-two percent of the rise in foreign cash occurs in firms with positive R\&D expenditures and positive related sales. The rise in (foreign) cash is concentrated in a small number of low tax countries and a well-defined set of firms.

Our results indicate that at least two important considerations are at work in explaining level of corporate liquidity: precautionary savings and taxes. The increase, however, arises primarily from tax motivations. These results suggest that the recently enacted corporate tax 
reforms could lead to a significant reduction in corporate cash levels, irrespective of any changes in investment uncertainty or capital market access. 


\section{References}

Albertus, J. F, 2016, "Does Foreign Tax Arbitrage Promote Innovation? Evidence from Subsidiary-Level Data" working paper.

Bates, Thomas, Kathy. Kahle, and Rene. Stulz, 2009, "Why Do U.S. Firms Hold So Much More Cash than They Used To?” Journal of Finance 64, 1985-2021.

Bloomberg BNA, 2018 "GILTI and FDII: Encouraging U.S. Ownership of Intangibles and Protecting the U.S. Tax Base" February 27.

Blouin, Jennifer and Linda Krull, 2014, "Does Organizational Form Affect Firms' Foreign Operations? The Role of "Check-the-Box" on Multinational Tax Planning?" University of Pennsylvania Working Paper.

Bowers, Simon, 2014, Luxembourg tax files: how tiny state rubber-stamped tax avoidance on an industrial scale, The Guardian, November 5, 2014.

Boyle, G. W. and G. A. Guthrie, 2003, "Investment, Uncertainty, and Liquidity," Journal of Finance 58, 2143-2166.

Denis, David and Stephen McKeon, 2017, "Persistent Operating Losses and Corporate Financial Policies" University of Pittsburgh working paper.

De Simone, Lisa, Huang and Linda Krull, 2017, "R\&D and the rising foreign profitability of U.S. multinational corporations" working paper.

De Simone, Lisa, and Rebecca Lester, 2017, “The Effect of Foreign Cash Holdings on Internal Capital Markets and Firm Financing" working paper.

De Simone, Lisa, Lillian Mills, and Bridget Stomberg, 2017, "Using IRS Audit Data to Identify Income Shifting to Foreign Affiliates" working paper.

De Simone, Lisa, Joseph Piotroski, and Rimmy Tomy, 2017, "Repatriation Taxes and Foreign Cash Holdings: The Impact of Anticipated Tax Reform” working paper.

Dobridge, C., and P. Landefeld, 2017, "Is the Cash Locked Out? Evidence from U.S. Multinational Tax Filings" working paper, Federal Reserve Board of Governors, Washington, D.C.).

Drawbaugh, K., and A. Sullivan, 2013, “Insight: How Treasury's Tax Loophole Mistake Saves Companies Billions Each Year,” Reuters.com, May 30, 2013.

Duchin, R., T. Gilbert, J. Harford, and C. M. Hrdlicka, 2017, "Precautionary Savings with Risky Assets: When Cash Is Not Cash," Journal of Finance 72, 793-852. 
Dyreng, Scott D. and Bradley P. Lindsey, 2009, "Using Financial Accounting Data to Examine the Effect of Foreign Operations Located in Tax Havens and Other Countries on U. S. Multinational Firms' Tax Rates," Journal of Accounting Research 47, 1283-1316.

Faulkender, M. W., and J. M. Smith, 2016, "Taxes and Leverage at Multinational Corporations," Journal of Financial Economics 122, 1-20.

Faulkender, M. W., and M. A. Petersen, 2012, "Investment and Capital Constraints: Repatriations under the American Jobs Creation Act," Review of Financial Studies 25, 3351-3388.

Foley, C. F., J. C. Hartzell, S. Titman, G. Twite, 2007, "Why Do Firms Hold So Much Cash? A Tax-based Explanation," Journal of Financial Economics 86, 579-607.

Graham, John and Mark Leary, 2018, “The Evolution of Corporate Cash” working paper.

Graham, John, Michelle Hanlon, and Terry Shevlin, 2010, Barriers to Mobility: The Lockout Effect of U.S. Taxation of Worldwide Corporate Profits, National Tax Journal 63 1111-1144.

Grubert, H., and J. Mutti, 1991, "Taxes, Tariffs and Transfer Pricing in Multinational Corporate Decision Making," Review of Economics and Statistics 73, 285-293.

Grubert, H., 2003, "Intangible Income, Intercompany Transactions, Income Shifting, and the Choice of Location," National Tax Journal 56, 221-242.

Guveneny, Fatih, Raymond J. Mataloni Jr., Dylan G. Rassierx, and Kim J. Ruhl, 2018, “Offshore Profit Shifting and Domestic Productivity Measurement" working paper.

Hanlon, Michelle, Rebecca Lester, and Rodrigo Verdi, 2015, "The effect of repatriation tax costs on U.S. multinational investment," Journal of Financial Economics 116, 179-196.

Harford, J., S. Klasa, and W. F. Maxwell, 2014, "Refinancing Risk and Cash Holdings," Journal of Finance 69, 975-1012.

Harford, J., C. Wang, and K. Zhang, 2017, "Foreign Cash: Taxes, Internal Capital Markets and Agency Problems," Review of Financial Studies 20, 1490-1538.

Harris, Benjamin and Adam Looney, 2018 "The Tax Cuts and Jobs Act: A Missed Opportunity To Establish A Sustainable Tax Code" May 24, Tax Policy Center - Urban Institute \& Brookings Institution.

He, Zhaozhao and M. Babajide Wintoki, 2016 "The cost of innovation: R\&D and high cash holdings in U.S. firms," Journal of Applied Corporate Finance 41, 280-303.

Hoberg, G., G. Phillips, and N. Prabhala, 2014, "Product Market Threats, Payouts, and Financial Flexibility," Journal of Finance 69, 293-324. 
Huynh, Quyen, Tom Quinn, and Paige Hill, 2018, "Tax Reform Readiness: Base Erosion and Antiabuse Tax, PWC.

Levin, C, and J. McCain, 2013, "Offshore Profit Shifting and the U.S. Tax Code - Part 2 (Apple Inc.)," (memo, Senate Permanent Committee on Investigations, Washington D.C.).

Kanter, J. 2014, “E.U. Accuses Starbucks and Netherlands of Making Unfair Tax Deal," The New York Times, November 14.

Karnitschnig, Matthew, and Robin Van Dallen, 2014, "Business-Friendly Bureaucrat Helped Build Tax Haven in Luxembourg," The Wall Street Journal, October 21, 2014.

Klassen, Kenneth and Stacie Laplante, 2012, "Are U.S. Multinational Corporations Becoming More Aggressive Income Shifters?” Journal of Accounting Research 50: 1245-1285.

Lattman, Peter and Peter Eavis, 2013, "To satisfy its investors, cash-rich Apple borrows money," New York Times, April 30.

Martin, J. S. and A. M. Santomero, 1997, "Investment Opportunities and Corporate Demand for Lines of Credit," Journal of Banking \& Finance 21, 1331-1350.

Opler, T., L. Pinkowitz, R. Stulz, and R. Williamson, 1999, “The Determinants and Implications of Corporate Cash Holdings," Journal of Financial Economics 52, 3-46.

Pinkowitz, L., R. Stulz, and R. Williamson, 2016, "Do U.S. Firms Hold More Cash than Foreign Firms Do?" Review of Financial Studies 29, 309-348.

Petersen, M. 2009, "Estimating Standard Errors in Finance Panel Data Sets: Comparing Approaches," Review of Financial Studies 22, 435-480.

Worstall, Tim, 2015, "Why Apple Is Borrowing \$6.5 Billion And What Obama's Trying To Do About It," Forbes, February 3. 
Table 1: Distribution of Cash and Sales across Subsidiary Countries

\begin{tabular}{lrrr|lrrr}
\hline & 1998 & & & & 2008 & \\
\hline Country & Foreign & Foreign & Corporate & Country & Foreign & Foreign & Corporate \\
Cash $\%$ & Sales $\%$ & Tax Rate & & Sales \% & $\begin{array}{r}\text { Tax Rate } \\
\text { Cash }\end{array}$ \\
\hline United Kingdom & $14.6 \%$ & $14.8 \%$ & $27.3 \%$ & Ireland & $13.1 \%$ & $4.0 \%$ & $12.5 \%$ \\
Netherlands & $10.4 \%$ & $5.8 \%$ & $35.0 \%$ & United Kingdom & $11.1 \%$ & $12.7 \%$ & $26.1 \%$ \\
Ireland & $9.0 \%$ & $2.0 \%$ & $32.0 \%$ & Bermuda & $9.9 \%$ & $1.1 \%$ & $0.0 \%$ \\
Germany & $6.9 \%$ & $10.6 \%$ & $56.6 \%$ & Netherlands & $9.9 \%$ & $4.7 \%$ & $24.3 \%$ \\
Belgium & $5.8 \%$ & $2.5 \%$ & $37.2 \%$ & Belgium & $5.6 \%$ & $2.4 \%$ & $31.1 \%$ \\
France & $5.4 \%$ & $6.0 \%$ & $41.7 \%$ & Luxembourg & $5.5 \%$ & $0.4 \%$ & $0.0 \%$ \\
Switzerland & $5.1 \%$ & $2.9 \%$ & $27.8 \%$ & Canada & $5.0 \%$ & $10.0 \%$ & $30.9 \%$ \\
Canada & $4.3 \%$ & $11.1 \%$ & $44.6 \%$ & Germany & $4.6 \%$ & $7.0 \%$ & $30.9 \%$ \\
Bermuda & $4.2 \%$ & $0.6 \%$ & $0.0 \%$ & Switzerland & $4.1 \%$ & $4.5 \%$ & $7.8 \%$ \\
Italy & $3.5 \%$ & $3.1 \%$ & $33.0 \%$ & France & $2.9 \%$ & $3.9 \%$ & $34.4 \%$ \\
Singapore & $2.9 \%$ & $3.2 \%$ & $26.0 \%$ & Australia & $2.5 \%$ & $2.9 \%$ & $30.0 \%$ \\
Japan & $2.6 \%$ & $7.8 \%$ & $51.6 \%$ & Japan & $2.2 \%$ & $5.4 \%$ & $43.0 \%$ \\
Australia & $2.1 \%$ & $2.8 \%$ & $36.0 \%$ & Singapore & $1.9 \%$ & $4.9 \%$ & $18.0 \%$ \\
Brazil & $2.0 \%$ & $3.6 \%$ & $25.0 \%$ & Italy & $1.7 \%$ & $2.6 \%$ & $27.5 \%$ \\
Spain & $1.9 \%$ & $2.1 \%$ & $35.0 \%$ & China & $1.6 \%$ & $3.5 \%$ & $25.0 \%$ \\
Other Countries & $19.3 \%$ & $21.0 \%$ & & Other Countries & $18.3 \%$ & $30.2 \%$ & \\
\hline Top 6 Countries & $52.0 \%$ & $42.0 \%$ & $38.3 \%$ & Top 6 Countries & $55.0 \%$ & $25 \%$ & $15.7 \%$ \\
\hline
\end{tabular}

Notes:

This table contains the fraction of total foreign cash held by subsidiaries in each country and the fraction of total foreign sales originating from subsidiaries in each country. The numbers are reported for 1998 (the beginning of our sample) and 2008 (the end of our sample). The top 15 countries (sorted by cash) are reported in each year along with the fraction of cash and sales in the subsidiaries from the remaining countries. The table also reports the statistics for the top six countries in each year. For example, foreign subsidiaries located in the United Kingdom held $14.6 \%$ of the cash and generated $14.8 \%$ of foreign sales in 1998 . The table also reports the top corporate statutory tax rate for each country in 1998 and 2008 as per Faulkender and Smith (2016). 
Table 2: Summary Statistics

\begin{tabular}{lcccc}
\hline \multirow{2}{*}{ Variable } & \multicolumn{2}{c}{ Full Sample } & \multicolumn{2}{c}{ Multinationals } \\
\cline { 2 - 5 } & Mean & $\begin{array}{c}\text { Standard } \\
\text { Deviation }\end{array}$ & Mean & $\begin{array}{c}\text { Standard } \\
\text { Deviation }\end{array}$ \\
\hline Foreign Cash to Assets & 0.015 & 0.248 & 0.089 & 0.147 \\
Domestic Cash to Assets & 0.210 & 0.245 & 0.122 & 0.179 \\
Total Cash to Assets & 0.225 & 0.249 & 0.211 & 0.206 \\
Effective Tax Rate & 0.347 & 0.022 & 0.330 & 0.051 \\
Ln(Sales) & 4.788 & 2.505 & 6.656 & 1.982 \\
Firm Has Bond Rating & 0.209 & 0.406 & 0.453 & 0.498 \\
PPE to Assets & 0.276 & 0.247 & 0.250 & 0.193 \\
Return on Assets & -0.018 & 0.322 & 0.104 & 0.152 \\
Firm Pays Dividends & 0.325 & 0.468 & 0.480 & 0.500 \\
R\&D to Sales & 0.199 & 0.597 & 0.073 & 0.245 \\
Market to Book & 3.179 & 3.151 & 2.275 & 2.128 \\
Book Leverage & 0.380 & 0.502 & 0.372 & 0.384 \\
Capital Expenditure/Assets & 0.066 & 0.093 & 0.049 & 0.053 \\
St Dev(Cash Flow) & 0.155 & 0.240 & 0.060 & 0.097 \\
\hline
\end{tabular}

Notes:

This table contains the means and standard deviations of the foreign, domestic, and total cash to book assets ratio as well as the control variables used in the analysis. The statistics are provided for both the full sample (78,336 firm-year observations) as well as for only those in the BEA multinational (MNC) survey (13,153 firm-year observations). Data definitions can be found in the text. All variables are winsorized at the $1^{\text {st }}$ and $99^{\text {th }}$ percentiles. 
Table 3: Baseline Cash Regressions

\begin{tabular}{|c|c|c|c|c|c|c|c|c|}
\hline & $\mathrm{I}$ & II & III & IV & $\mathrm{V}$ & VI & VII & VIII \\
\hline & $\begin{array}{l}\text { Total } \\
\text { Cash }\end{array}$ & $\begin{array}{l}\text { Total } \\
\text { Cash }\end{array}$ & $\begin{array}{c}\text { Domestic } \\
\text { Cash }\end{array}$ & $\begin{array}{c}\text { Domestic } \\
\text { Cash }\end{array}$ & $\begin{array}{c}\text { Domestic } \\
\text { Cash }\end{array}$ & $\begin{array}{l}\text { Foreign } \\
\text { Cash }\end{array}$ & $\begin{array}{l}\text { Foreign } \\
\text { Cash }\end{array}$ & $\begin{array}{l}\text { Foreign } \\
\text { Cash }\end{array}$ \\
\hline & All Firms & $\mathrm{MNC}$ & All Firms & MNC & $\mathrm{MNC}$ & $\mathrm{MNC}$ & $\mathrm{MNC}$ & $\begin{array}{c}\text { MNC } \\
\text { High For } \\
\text { Income }\end{array}$ \\
\hline Effective Tax Rate & $\begin{array}{l}-0.736^{1} \\
(0.073)\end{array}$ & $\begin{array}{l}-0.679^{1} \\
(0.073)\end{array}$ & $\begin{array}{r}0.069 \\
(0.046)\end{array}$ & $\begin{array}{c}0.063 \\
(0.048)\end{array}$ & $\begin{array}{c}0.057 \\
(0.048)\end{array}$ & $\begin{array}{l}-0.743^{1} \\
(0.076)\end{array}$ & $\begin{array}{l}-0.759^{1} \\
(0.078)\end{array}$ & $\begin{array}{l}-1.111^{1} \\
(0.202)\end{array}$ \\
\hline Ln(Firm Sales) & $\begin{array}{l}-0.016^{1} \\
(0.001)\end{array}$ & $\begin{array}{l}-0.005^{*} \\
(0.003)\end{array}$ & $\begin{array}{l}-0.017^{1} \\
(0.001)\end{array}$ & $\begin{array}{l}-0.012^{1} \\
(0.002)\end{array}$ & $\begin{array}{l}-0.010^{1} \\
(0.002)\end{array}$ & $\begin{array}{r}0.008^{1} \\
(0.002)\end{array}$ & $\begin{array}{r}0.008^{1} \\
(0.002)\end{array}$ & $\begin{array}{l}-0.002 \\
(0.002)\end{array}$ \\
\hline Has Bond Rating & $\begin{array}{r}0.010^{1} \\
(0.004)\end{array}$ & $\begin{array}{c}0.003 \\
(0.008)\end{array}$ & $\begin{array}{r}0.007^{5} \\
(0.003)\end{array}$ & $\begin{array}{l}-0.005 \\
(0.007)\end{array}$ & $\begin{array}{l}-0.007 \\
(0.007)\end{array}$ & $\begin{array}{c}0.008 \\
(0.006)\end{array}$ & $\begin{array}{c}0.008 \\
(0.007)\end{array}$ & $\begin{array}{l}-0.002 \\
(0.004)\end{array}$ \\
\hline PPE to Book Assets & $\begin{array}{l}-0.321^{1} \\
(0.006)\end{array}$ & $\begin{array}{l}-0.272^{1} \\
(0.018)\end{array}$ & $\begin{array}{l}-0.313^{1} \\
(0.006)\end{array}$ & $\begin{array}{l}-0.188^{1} \\
(0.015)\end{array}$ & $\begin{array}{l}-0.171^{1} \\
(0.015)\end{array}$ & $\begin{array}{l}-0.083^{1} \\
(0.016)\end{array}$ & $\begin{array}{l}-0.080^{1} \\
(0.016)\end{array}$ & $\begin{array}{l}-0.027^{*} \\
(0.014)\end{array}$ \\
\hline Return on Assets & $\begin{array}{r}0.027^{1} \\
(0.006)\end{array}$ & $\begin{array}{l}-0.080^{5} \\
(0.035)\end{array}$ & $\begin{array}{r}0.031^{1} \\
(0.005)\end{array}$ & $\begin{array}{r}0.005 \\
(0.027)\end{array}$ & $\begin{array}{c}0.039 \\
(0.028)\end{array}$ & $\begin{array}{l}-0.085^{5} \\
(0.038)\end{array}$ & $\begin{array}{l}-0.093^{5} \\
(0.038)\end{array}$ & $\begin{array}{l}-0.127^{5} \\
(0.053)\end{array}$ \\
\hline Firm Pays Dividends & $\begin{array}{l}-0.013^{1} \\
(0.003)\end{array}$ & $\begin{array}{l}-0.024^{1} \\
(0.007)\end{array}$ & $\begin{array}{l}-0.014^{1} \\
(0.003)\end{array}$ & $\begin{array}{l}-0.033^{1} \\
(0.006)\end{array}$ & $\begin{array}{l}-0.032^{1} \\
(0.006)\end{array}$ & $\begin{array}{c}0.009 \\
(0.006)\end{array}$ & $\begin{array}{c}0.010 \\
(0.006)\end{array}$ & $\begin{array}{c}0.004 \\
(0.003)\end{array}$ \\
\hline$R \& D$ to Sales & $\begin{array}{r}0.136^{1} \\
(0.003)\end{array}$ & $\begin{array}{r}0.280^{1} \\
(0.032)\end{array}$ & $\begin{array}{r}0.136^{1} \\
(0.003)\end{array}$ & $\begin{array}{r}0.272^{1} \\
(0.031)\end{array}$ & $\begin{array}{r}0.268^{1} \\
(0.033)\end{array}$ & $\begin{array}{c}0.008 \\
(0.016)\end{array}$ & $\begin{array}{l}0.007 \\
(0.016)\end{array}$ & $\begin{array}{l}-0.021 \\
(0.017)\end{array}$ \\
\hline Market to Book & $\begin{array}{r}0.004^{1} \\
(0.000)\end{array}$ & $\begin{array}{r}0.010^{1} \\
(0.002)\end{array}$ & $\begin{array}{r}0.004^{1} \\
(0.000)\end{array}$ & $\begin{array}{r}0.010^{1} \\
(0.001)\end{array}$ & $\begin{array}{r}0.010^{1} \\
(0.002)\end{array}$ & $\begin{array}{c}0.000 \\
(0.001)\end{array}$ & $\begin{array}{c}0.001 \\
(0.001)\end{array}$ & $\begin{array}{c}0.002^{*} \\
(0.001)\end{array}$ \\
\hline Book Leverage & $\begin{array}{l}-0.096^{1} \\
(0.003)\end{array}$ & $\begin{array}{l}-0.107^{1} \\
(0.010)\end{array}$ & $\begin{array}{l}-0.096^{1} \\
(0.003)\end{array}$ & $\begin{array}{l}-0.107^{1} \\
(0.009)\end{array}$ & $\begin{array}{l}-0.102^{1} \\
(0.009)\end{array}$ & $\begin{array}{l}-0.000 \\
(0.006)\end{array}$ & $\begin{array}{l}-0.002 \\
(0.006)\end{array}$ & $\begin{array}{c}0.000 \\
(0.006)\end{array}$ \\
\hline Capital Exp/Sales & $\begin{array}{r}0.081^{1} \\
(0.010)\end{array}$ & $\begin{array}{r}0.256^{1} \\
(0.051)\end{array}$ & $\begin{array}{r}0.074^{1} \\
(0.010)\end{array}$ & $\begin{array}{r}0.207^{1} \\
(0.046)\end{array}$ & $\begin{array}{r}0.170^{1} \\
(0.046)\end{array}$ & $\begin{array}{c}0.050 \\
(0.040)\end{array}$ & $\begin{array}{c}0.043 \\
(0.040)\end{array}$ & $\begin{array}{c}0.014 \\
(0.033)\end{array}$ \\
\hline StDev(Cash Flow) & & & & & $\begin{array}{r}0.169^{1} \\
(0.040)\end{array}$ & & $\begin{array}{c}0.042 \\
(0.028)\end{array}$ & \\
\hline $\begin{array}{l}\text { Domestic Firm } \\
\text { (1 if yes) }\end{array}$ & $\begin{array}{l}-0.012^{1} \\
(0.004)\end{array}$ & & $\begin{array}{r}0.060^{1} \\
(0.004)\end{array}$ & & & & & \\
\hline Observations & 78,164 & 12,318 & 78,164 & 12,318 & 11,847 & 12,318 & 11,847 & 6,524 \\
\hline $\mathrm{R}^{2}$ & 0.393 & 0.313 & 0.413 & 0.335 & 0.338 & 0.108 & 0.111 & 0.070 \\
\hline
\end{tabular}

Notes:

The table contains regressions of the ratio of the firm's cash to book assets on a set of firm characteristics. Cash is defined as total cash (columns I and II), domestic cash (columns III-V), and foreign cash (columns VI-VIII) divided by net assets. The entire sample is included in the regression in columns I and III. Only multinational firms (MNC) are included in the sample in columns II and IV-VIII. The sample in Column VIII includes only MNCs whose foreign source income percentage is above the median. Each regression contains year dummies. Standard errors are clustered by firm. Statistical significance at the 1 , or 5 or $10 \%$ levels is reported as superscripts 1,5 , and $*$ respectively. 
Table 4: Related Sales Cash Regressions

\begin{tabular}{|c|c|c|c|c|c|c|c|c|c|}
\hline & I & II & III & IV & V & VI & VII & VIII & IX \\
\hline & $\begin{array}{c}\text { Domestic } \\
\text { Cash }\end{array}$ & $\begin{array}{l}\text { Foreign } \\
\text { Cash }\end{array}$ & $\begin{array}{l}\text { Foreign } \\
\text { Cash }\end{array}$ & $\begin{array}{l}\text { Foreign } \\
\text { Cash }\end{array}$ & $\begin{array}{l}\text { Domestic } \\
\text { Cash }\end{array}$ & $\begin{array}{l}\text { Foreign } \\
\text { Cash }\end{array}$ & $\begin{array}{l}\text { Foreign } \\
\text { Cash }\end{array}$ & $\begin{array}{l}\text { Foreign } \\
\text { Cash }\end{array}$ & $\begin{array}{l}\text { Foreign } \\
\text { Cash }(\Delta)\end{array}$ \\
\hline & $\mathrm{MNC}$ & $\mathrm{MNC}$ & $\begin{array}{c}\mathrm{MNC} \\
\mathrm{R} \& \mathrm{D}=0\end{array}$ & $\begin{array}{c}\mathrm{MNC} \\
\mathrm{R} \& \mathrm{D}>0\end{array}$ & $\mathrm{MNC}$ & $\mathrm{MNC}$ & $\begin{array}{c}\mathrm{MNC} \\
\mathrm{R} \& \mathrm{D}=0\end{array}$ & $\begin{array}{c}\mathrm{MNC} \\
\mathrm{R} \& \mathrm{D}>0\end{array}$ & $\begin{array}{c}\mathrm{MNC} \\
\mathrm{R} \& \mathrm{D}>0\end{array}$ \\
\hline Related Sales & $\begin{array}{l}-0.091^{5} \\
(0.035)\end{array}$ & $\begin{array}{c}0.361^{1} \\
(0.093)\end{array}$ & $\begin{array}{c}0.088 \\
(0.156)\end{array}$ & $\begin{array}{r}0.414^{1} \\
(0.097)\end{array}$ & $\begin{array}{l}-0.054^{1} \\
(0.019)\end{array}$ & $\begin{array}{r}0.175^{1} \\
(0.033)\end{array}$ & $\begin{array}{r}0.121^{1} \\
(0.026)\end{array}$ & $\begin{array}{r}0.190^{1} \\
(0.045)\end{array}$ & $\begin{array}{r}0.077^{5} \\
(0.037)\end{array}$ \\
\hline Effective Tax Rate & $\begin{array}{l}-0.042 \\
(0.057)\end{array}$ & $\begin{array}{l}-0.347^{1} \\
(0.060)\end{array}$ & $\begin{array}{l}-0.389^{1} \\
(0.088)\end{array}$ & $\begin{array}{l}-0.315^{1} \\
(0.078)\end{array}$ & & & & & $\begin{array}{l}-0.059^{5} \\
(0.029)\end{array}$ \\
\hline $\begin{array}{c}\text { Related Sales } \\
\text { x Tax Rate }\end{array}$ & $\begin{array}{c}0.049 \\
(0.113)\end{array}$ & $\begin{array}{l}-0.315 \\
(0.284)\end{array}$ & $\begin{array}{c}0.321 \\
(0.465)\end{array}$ & $\begin{array}{l}-0.486^{*} \\
(0.295)\end{array}$ & & & & & $\begin{array}{l}-0.176 \\
(0.113)\end{array}$ \\
\hline $\begin{array}{l}\text { Tax Haven } \\
\text { (1 if yes) }\end{array}$ & & & & & $\begin{array}{l}-0.003 \\
(0.006)\end{array}$ & $\begin{array}{r}0.043^{1} \\
(0.005)\end{array}$ & $\begin{array}{r}0.041^{1} \\
(0.007)\end{array}$ & $\begin{array}{r}0.043^{1} \\
(0.007)\end{array}$ & \\
\hline $\begin{array}{l}\text { Related Sales } \\
\text { x Tax Haven }\end{array}$ & & & & & $\begin{array}{l}-0.026 \\
(0.022)\end{array}$ & $\begin{array}{r}0.135^{1} \\
(0.043)\end{array}$ & $\begin{array}{c}0.096 \\
(0.067)\end{array}$ & $\begin{array}{r}0.126^{5} \\
(0.054)\end{array}$ & \\
\hline Ln(Firm Sales) & $\begin{array}{l}-0.011^{1} \\
(0.002)\end{array}$ & $\begin{array}{c}0.002 \\
(0.002)\end{array}$ & $\begin{array}{l}-0.003 \\
(0.002)\end{array}$ & $\begin{array}{r}0.005^{*} \\
(0.003)\end{array}$ & $\begin{array}{l}-0.010^{1} \\
(0.002)\end{array}$ & $\begin{array}{l}-0.002 \\
(0.002)\end{array}$ & $\begin{array}{l}-0.006^{5} \\
(0.002)\end{array}$ & $\begin{array}{l}-0.000 \\
(0.003)\end{array}$ & $\begin{array}{r}0.002^{5} \\
(0.001)\end{array}$ \\
\hline Has Bond Rating & $\begin{array}{l}-0.005 \\
(0.007)\end{array}$ & $\begin{array}{c}0.006 \\
(0.006)\end{array}$ & $\begin{array}{c}0.001 \\
(0.006)\end{array}$ & $\begin{array}{c}0.009 \\
(0.009)\end{array}$ & $\begin{array}{l}-0.005 \\
(0.007)\end{array}$ & $\begin{array}{c}0.005 \\
(0.006)\end{array}$ & $\begin{array}{c}0.003 \\
(0.006)\end{array}$ & $\begin{array}{c}0.007 \\
(0.009)\end{array}$ & $\begin{array}{c}0.001 \\
(0.003)\end{array}$ \\
\hline PPE to Book Assets & $\begin{array}{l}-0.191^{1} \\
(0.015)\end{array}$ & $\begin{array}{l}-0.072^{1} \\
(0.014)\end{array}$ & $\begin{array}{l}-0.068^{1} \\
(0.013)\end{array}$ & $\begin{array}{l}-0.056^{*} \\
(0.030)\end{array}$ & $\begin{array}{l}-0.193^{1} \\
(0.015)\end{array}$ & $\begin{array}{l}-0.065^{1} \\
(0.013)\end{array}$ & $\begin{array}{l}-0.060^{1} \\
(0.012)\end{array}$ & $\begin{array}{l}-0.060^{5} \\
(0.030)\end{array}$ & $\begin{array}{c}0.002 \\
(0.009)\end{array}$ \\
\hline Return on Assets & $\begin{array}{c}0.009 \\
(0.027)\end{array}$ & $\begin{array}{l}-0.096^{1} \\
(0.036)\end{array}$ & $\begin{array}{l}-0.040 \\
(0.034)\end{array}$ & $\begin{array}{l}-0.134^{1} \\
(0.048)\end{array}$ & $\begin{array}{c}0.007 \\
(0.027)\end{array}$ & $\begin{array}{l}-0.093^{5} \\
(0.036)\end{array}$ & $\begin{array}{l}-0.036 \\
(0.034)\end{array}$ & $\begin{array}{l}-0.126^{1} \\
(0.048)\end{array}$ & $\begin{array}{l}-0.070^{*} \\
(0.014)\end{array}$ \\
\hline Firm Pays Dividends & $\begin{array}{l}-0.033^{1} \\
(0.006)\end{array}$ & $\begin{array}{l}0.011^{5} \\
(0.005)\end{array}$ & $\begin{array}{c}0.001 \\
(0.006)\end{array}$ & $\begin{array}{l}0.016^{5} \\
(0.007)\end{array}$ & $\begin{array}{l}-0.034^{1} \\
(0.006)\end{array}$ & $\begin{array}{c}0.007 \\
(0.005)\end{array}$ & $\begin{array}{l}-0.001 \\
(0.006)\end{array}$ & $\begin{array}{c}0.012 \\
(0.007)\end{array}$ & $\begin{array}{c}0.000 \\
(0.002)\end{array}$ \\
\hline R\&D to Sales & $\begin{array}{r}0.279^{1} \\
(0.032)\end{array}$ & $\begin{array}{l}-0.016 \\
(0.014)\end{array}$ & & $\begin{array}{l}-0.030^{*} \\
(0.017)\end{array}$ & $\begin{array}{r}0.280^{1} \\
(0.032)\end{array}$ & $\begin{array}{l}-0.024^{*} \\
(0.014)\end{array}$ & & $\begin{array}{l}-0.036^{5} \\
(0.017)\end{array}$ & $\begin{array}{l}-0.009^{5} \\
(0.005)\end{array}$ \\
\hline Market to Book & $\begin{array}{c}0.010^{1} \\
(0.001)\end{array}$ & $\begin{array}{c}0.000 \\
(0.001)\end{array}$ & $\begin{array}{c}0.000 \\
(0.001)\end{array}$ & $\begin{array}{c}0.000 \\
(0.002)\end{array}$ & $\begin{array}{c}0.010^{1} \\
(0.001)\end{array}$ & $\begin{array}{c}0.000 \\
(0.001)\end{array}$ & $\begin{array}{l}-0.000 \\
(0.001)\end{array}$ & $\begin{array}{c}0.000 \\
(0.001)\end{array}$ & $\begin{array}{c}0.001 \\
(0.001)\end{array}$ \\
\hline Book Leverage & $\begin{array}{l}-0.106^{1} \\
(0.009)\end{array}$ & $\begin{array}{l}-0.003 \\
(0.006)\end{array}$ & $\begin{array}{l}-0.002 \\
(0.007)\end{array}$ & $\begin{array}{l}-0.003 \\
(0.009)\end{array}$ & $\begin{array}{l}-0.106^{1} \\
(0.009)\end{array}$ & $\begin{array}{l}-0.003 \\
(0.006)\end{array}$ & $\begin{array}{l}-0.004 \\
(0.007)\end{array}$ & $\begin{array}{l}-0.001 \\
(0.009)\end{array}$ & $\begin{array}{c}0.002 \\
(0.004)\end{array}$ \\
\hline Capital Exp/Sales & $\begin{array}{r}0.205^{1} \\
(0.046) \\
\end{array}$ & $\begin{array}{c}0.057 \\
(0.036) \\
\end{array}$ & $\begin{array}{c}0.059^{*} \\
(0.035) \\
\end{array}$ & $\begin{array}{c}0.044 \\
(0.079) \\
\end{array}$ & $\begin{array}{r}0.205^{1} \\
(0.046) \\
\end{array}$ & $\begin{array}{c}0.058 \\
(0.036) \\
\end{array}$ & $\begin{array}{c}0.050 \\
(0.035) \\
\end{array}$ & $\begin{array}{c}0.058 \\
(0.080) \\
\end{array}$ & $\begin{array}{c}0.032 \\
(0.033)\end{array}$ \\
\hline $\begin{array}{l}\text { Observations } \\
\mathrm{R}^{2}\end{array}$ & $\begin{array}{l}12,318 \\
0.343\end{array}$ & $\begin{array}{l}12,318 \\
0.248\end{array}$ & $\begin{array}{l}4,691 \\
0.144\end{array}$ & $\begin{array}{l}7,627 \\
0.267\end{array}$ & $\begin{array}{l}12,258 \\
0.344\end{array}$ & $\begin{array}{c}12,258 \\
0.264\end{array}$ & $\begin{array}{l}4,665 \\
0.163\end{array}$ & $\begin{array}{l}7,593 \\
0.276\end{array}$ & $\begin{array}{l}7,107 \\
0.058\end{array}$ \\
\hline
\end{tabular}

Notes:

The table contains regressions of the ratio of the firm's cash to book assets on a set of firm characteristics for multinational firms. Cash is defined as domestic cash (columns I and V), foreign cash (columns II-IV and VI-VIII) or change in foreign cash (IX). Related sales is defined as the percent of the firm's total sales that are sales made by its subsidiaries to other subsidiaries or to the parent. The sample includes only multinational firms (MNC). Columns III and VII contain only firm-years with zero reported R\&D while column IV and VIII contain only firm-years with strictly positive reported R\&D. In columns V-VIII, the effective tax rate is replaced by a tax haven dummy, which is equal to one if the firm has a subsidiary in a tax haven as defined by the Global Policy Forum (see Dyreng and Lindsey, 2009). Each regression contains year dummies. Standard errors are clustered by firm. Statistical significance at the 1, or 5 or $10 \%$ levels is reported as superscripts 1,5 , and $*$ respectively. 
Table 5: Related Sales Cash Regressions - Includes Fixed Effects

\begin{tabular}{lccc}
\hline & I & II & III \\
\hline & $\begin{array}{c}\text { Foreign } \\
\text { Cash }\end{array}$ & $\begin{array}{c}\text { Foreign } \\
\text { Cash }\end{array}$ & $\begin{array}{c}\text { Foreign } \\
\text { Cash }\end{array}$ \\
\cline { 2 - 4 } & MNC & $\begin{array}{c}\text { MNC } \\
\text { R\&D }=0\end{array}$ & $\begin{array}{c}\text { MNC } \\
\text { R\&D }>0\end{array}$ \\
\hline Related Sales & $0.276^{1}$ & -0.044 & $0.333^{1}$ \\
& $(0.022)$ & $(0.043)$ & $(0.027)$ \\
Effective Tax Rate & $-0.092^{1}$ & $-0.213^{1}$ & -0.017 \\
& $(0.031)$ & $(0.042)$ & $(0.043)$ \\
Related Sales & $-0.520^{1}$ & $0.377^{1}$ & $-0.692^{1}$ \\
$\quad$ Tax Rate & $(0.073)$ & $(0.136)$ & $(0.092)$ \\
\hline Observations & 12,318 & 4,691 & 7,627 \\
$\mathrm{R}^{2}$ & 0.715 & 0.655 & 0.731 \\
\hline
\end{tabular}

Notes:

This table contains regressions from Table4, columns II, III, and IV but with firm dummies included. These regression contain the same control variables, but only the tax variables are presented. The table contains regressions of the ratio of the firm's foreign cash to book assets on a set of firm characteristics. Related sales is defined as the percent of the firm's total sales that are sales made by its subsidiaries to other subsidiaries or to the parent. The sample includes only multinational firms (MNC). Column II contains only firm-years with zero reported R\&D while column III only contains firm-years with strictly positive reported R\&D. Each regression contains year dummies. Standard errors are clustered by firm. Statistical significance at the 1 , or 5 or $10 \%$ levels is reported as superscripts 1,5 , and * respectively. 
Table 6: Tax Variable Decomposition

\begin{tabular}{lcc}
\hline & I & II \\
\hline & $\begin{array}{c}\text { Domestic } \\
\text { Cash }\end{array}$ & $\begin{array}{c}\text { Foreign } \\
\text { Cash }\end{array}$ \\
\hline US Income (\%) & $0.042^{1}$ & $-0.129^{1}$ \\
& $(0.006)$ & $(0.008)$ \\
Foreign Tax Rate & -0.049 & $-0.144^{1}$ \\
Ln(Firm Sales) & $(0.026)$ & $(0.024)$ \\
Has Bond Rating & $-0.011^{1}$ & $0.008^{1}$ \\
& $(0.002)$ & $(0.002)$ \\
PPE to Book Assets & -0.006 & 0.007 \\
Return on Assets & $(0.007)$ & $(0.006)$ \\
& $-0.191^{1}$ & $-0.085^{1}$ \\
Firm Pays Dividends & $(0.015)$ & $(0.015)$ \\
& -0.012 & -0.027 \\
R\&D to Sales & $(0.028)$ & $(0.041)$ \\
& $-0.034^{1}$ & $0.011^{*}$ \\
Market to Book & $(0.005)$ & $(0.005)$ \\
Book Leverage & $0.267^{1}$ & 0.017 \\
& $(0.031)$ & $(0.016)$ \\
Capital Exp/Sales & $0.009^{1}$ & 0.001 \\
& $(0.001)$ & $(0.001)$ \\
Observations & $-0.106^{1}$ & -0.004 \\
& $(0.009)$ & $(0.006)$ \\
& $0.203^{1}$ & 0.051 \\
& $(0.046)$ & $(0.038)$ \\
\hline
\end{tabular}

Notes:

The table contains regressions of the ratio of the firm's domestic or foreign cash to book assets on a set of firm characteristics. Only multinational firms (MNC) are included in the sample. US Income is the percentage of the firm's earnings that were generated in the United States. Foreign Tax Rate is the subsidiary earnings weighted tax rate for the foreign subsidiaries in which the company operates. Each regression contains year dummies. Standard errors are clustered by firm. Statistical significance at the 1,5 , or $10 \%$ levels is reported as superscripts 1,5 , and ${ }^{*}$, respectively. 
Table 7: Changing Distribution of Foreign Income across Subsidiaries

\begin{tabular}{lcc}
\hline & I & II \\
\hline$\Delta$ Foreign Tax Rate & 0.002 & $-0.012^{5}$ \\
(1998-2008) & $(0.005)$ & $(0.005)$ \\
Tax Rate Differential (1998) & & $-0.026^{1}$ \\
Foreign - US & & $(0.005)$ \\
\hline Observations & 13,692 & 13,692 \\
$\mathrm{R}^{2}$ & 0.000 & 0.003 \\
\hline
\end{tabular}

Notes:

The table contains regressions of the change in the percent of income earned in a subsidiary (country) on changes in the foreign tax rates from 1998 to 2008. The regression contains variation across firms and subsidiaries (countries) but not time. If a subsidiary is added after 1998, the fraction of income in that subsidiary is set to zero in 1998. If a subsidiary is closed, the fraction of income in that subsidiary is set to zero in 2008. In column II, we also included the minimum of the foreign tax rate in 1998 minus $35 \%$ and 0 . Standard errors are clustered by firm. Statistical significance at the 1,5 , or $10 \%$ levels is reported as superscripts 1,5 , and *, respectively.

$$
\begin{aligned}
\text { [Foriegn Income } \left.\%_{\mathrm{i}, \mathrm{s}, 2008} \text {-Foriegn Income } \%_{\mathrm{i}, \mathrm{s}, 1998}\right] & =\beta_{0}+\beta_{1}\left[\text { Foriegn } \tau_{\mathrm{i}, \mathrm{s}, 2008}-\text { Foriegn } \tau_{\mathrm{i}, \mathrm{s}, 1998}\right] \\
& +\beta_{2} \operatorname{Min}\left[\text { Foriegn } \tau_{\mathrm{i}, \mathrm{s}, 1998}-0.35,0\right]
\end{aligned}
$$


Table 8: Subsidiary Level Cash Regressions - Firms with Positive R\&D

\begin{tabular}{lcccccccc}
\hline & I & II & III & IV & V & VI & VII & VIII \\
\hline Related Sales & $0.510^{1}$ & $0.471^{1}$ & $0.475^{1}$ & $0.477^{1}$ & $0.508^{1}$ & $0.466^{1}$ & $0.472^{1}$ & $0.471^{1}$ \\
& $(0.093)$ & $(0.087)$ & $(0.096)$ & $(0.091)$ & $(0.094)$ & $(0.088)$ & $(0.097)$ & $(0.093)$ \\
Foreign Tax Rate & $-0.030^{1}$ & $-0.025^{1}$ & $-0.023^{1}$ & 0.002 & $-0.028^{1}$ & $-0.015^{5}$ & $-0.014^{5}$ & 0.007 \\
& $(0.004)$ & $(0.004)$ & $(0.005)$ & $(0.005)$ & $(0.007)$ & $(0.006)$ & $(0.006)$ & $(0.008)$ \\
Related Sales & $-1.008^{1}$ & $-0.835^{1}$ & $-0.819^{5}$ & $-0.953^{1}$ & $-1.010^{1}$ & $-0.821^{1}$ & $-0.807^{5}$ & $-0.958^{1}$ \\
x Tax Rate & $(0.311)$ & $(0.290)$ & $(0.319)$ & $(0.305)$ & $(0.314)$ & $(0.292)$ & $(0.321)$ & $(0.309)$ \\
Subsidiary Sales & & & & & 0.005 & $0.009^{5}$ & $0.015^{1}$ & $0.011^{5}$ \\
& & & & & $(0.005)$ & $(0.004)$ & $(0.004)$ & $(0.005)$ \\
Subsidiary Sales & & & & & -0.004 & -0.017 & -0.016 & -0.008 \\
x Tax Rate & & & & & $(0.014)$ & $(0.012)$ & $(0.013)$ & $(0.015)$ \\
PPE & $0.279^{1}$ & $0.221^{1}$ & $0.227^{1}$ & $0.271^{1}$ & $0.279^{1}$ & $0.220^{1}$ & $0.227^{1}$ & $0.271^{1}$ \\
of subsidiary & $(0.028)$ & $(0.023)$ & $(0.026)$ & $(0.027)$ & $(0.028)$ & $(0.023)$ & $(0.026)$ & $(0.027)$ \\
R\&D & $0.004^{1}$ & $0.007^{1}$ & $0.007^{1}$ & $0.003^{1}$ & $0.004^{1}$ & $0.007^{1}$ & $0.007^{1}$ & $0.003^{1}$ \\
of subsidiary & $(0.001)$ & $(0.001)$ & $(0.001)$ & $(0.001)$ & $(0.001)$ & $(0.001)$ & $(0.001)$ & $(0.001)$ \\
Ln(GDP) & $0.002^{1}$ & $0.001^{1}$ & $0.001^{1}$ & $0.007^{1}$ & $0.002^{1}$ & $0.001^{1}$ & $0.001^{1}$ & $0.006^{1}$ \\
of country & $(0.000)$ & $(0.000)$ & $(0.000)$ & $(0.001)$ & $(0.000)$ & $(0.000)$ & $(0.000)$ & $(0.001)$ \\
\hline Firm Dummies & No & Yes & No & No & No & Yes & No & No \\
Firm-Year Dummies & No & No & Yes & No & No & No & Yes & No \\
Country Dummies & No & No & No & Yes & No & No & No & Yes \\
\hline Observations & 78,165 & 78,165 & 78,165 & 78,164 & 78,165 & 78,165 & 78,165 & 78,164 \\
R $^{2}$ & 0.175 & 0.32 & 0.406 & 0.207 & 0.176 & 0.320 & 0.406 & 0.209 \\
\hline
\end{tabular}

Notes:

The table contains regressions of the subsidiary's cash to book assets on a set of subsidiary characteristics. Each observation represents a MNC's subsidiary in a given year. Thus, a firm that has three subsidiaries will have three observations per year. The regressions include only observations for MNCs that report strictly positive R\&D. The foreign tax rate (the marginal tax rate the subsidiary faces in each country), related sales (the percent of the subsidiaries sales which are made to the parent or other subsidiaries of the parent), and the cross product are included in each regression. In columns V-VIII, we include the subsidiary sales (as a percent of total firm sales) as well as the cross produce of subsidiary sales and the foreign tax rate. The subsidiary's property, plant, and equipment (PPE) to book value of assets, the subsidiary R\&D/Sales ratio, and the natural $\log$ of GDP at the country level are included as additional explanatory variables. Standard errors are clustered by firm. Statistical significance at the 1,5, or 10\% levels is reported as superscripts 1,5 , and ${ }^{*}$, respectively. 
Table 9: Subsidiary Level Cash Regressions - Zero R\&D

\begin{tabular}{lcccccccc}
\hline & I & II & III & IV & V & VI & VII & VIII \\
\hline Related Sales & $0.327^{*}$ & $0.222^{*}$ & 0.194 & $0.301^{*}$ & $0.323^{*}$ & $0.224^{*}$ & 0.193 & 0.284 \\
& $(0.180)$ & $(0.128)$ & $(0.130)$ & $(0.172)$ & $(0.179)$ & $(0.127)$ & $(0.129)$ & $(0.173)$ \\
Foreign Tax Rate & $-0.026^{1}$ & $-0.028^{1}$ & $-0.030^{1}$ & 0.008 & $-0.034^{1}$ & $-0.030^{1}$ & $-0.029^{1}$ & 0.007 \\
& $(0.006)$ & $(0.006)$ & $(0.006)$ & $(0.007)$ & $(0.007)$ & $(0.006)$ & $(0.008)$ & $(0.011)$ \\
Related Sales & -0.542 & -0.276 & -0.015 & -0.481 & -0.561 & -0.283 & -0.011 & -0.465 \\
$\quad$ Tax Rate & $(0.543)$ & $(0.392)$ & $(0.428)$ & $(0.517)$ & $(0.542)$ & $(0.390)$ & $(0.426)$ & $(0.522)$ \\
Subsidiary Sales & & & & & 0.006 & 0.000 & $0.049^{1}$ & 0.014 \\
& & & & & $(0.008)$ & $(0.008)$ & $(0.012)$ & $(0.009)$ \\
Subsidiary Sales & & & & & 0.016 & 0.006 & -0.003 & 0.002 \\
x Tax Rate & & & & & $(0.022)$ & $(0.019)$ & $(0.022)$ & $(0.025)$ \\
PPE & $0.215^{1}$ & $0.149^{1}$ & $0.176^{1}$ & $0.209^{1}$ & $0.209^{1}$ & $0.149^{1}$ & $0.176^{1}$ & $0.199^{1}$ \\
of subsidiary & $(0.026)$ & $(0.021)$ & $(0.026)$ & $(0.026)$ & $(0.026)$ & $(0.021)$ & $(0.026)$ & $(0.025)$ \\
Ln(GDP) & $0.002^{1}$ & $0.002^{1}$ & $0.002^{1}$ & 0.002 & $0.003^{1}$ & $0.002^{1}$ & $0.002^{1}$ & 0.002 \\
of country & $(0.000)$ & $(0.000)$ & $(0.000)$ & $(0.003)$ & $(0.000)$ & $(0.000)$ & $(0.000)$ & $(0.003)$ \\
\hline Firm Dummies & No & Yes & No & No & No & Yes & No & No \\
Firm-Year Dummies & No & No & Yes & No & No & No & Yes & No \\
Country Dummies & No & No & No & Yes & No & No & No & Yes \\
\hline Observations & 28,687 & 28,687 & 28,687 & 28,687 & 28,687 & 28,687 & 28,687 & 28,687 \\
R $^{2}$ & 0.143 & 0.358 & 0.520 & 0.165 & 0.148 & 0.358 & 0.520 & 0.173 \\
\hline
\end{tabular}

Notes:

The table contains regressions of the subsidiary's cash to book assets on a set of subsidiary characteristics. Each observation represents a MNC's subsidiary in a given year. Thus, a firm that has three subsidiaries will have three observations per year. The regressions include only observations for MNCs that report zero or missing R\&D. The foreign tax rate (the marginal tax rate the subsidiary faces in each country), related sales (the percent of the subsidiaries sales which are made to the parent or other subsidiaries of the parent), and the cross product are included in each regression. In columns V-VIII, we include the subsidiary sales (as a percent of total firm sales) as well as the cross produce of subsidiary sales and the foreign tax rate. The subsidiary's property, plant, and equipment (PPE) to book value of assets, the subsidiary R\&D/Sales ratio, and the natural $\log$ of GDP at the country level are included as additional explanatory variables. Standard errors are clustered by firm. Statistical significance at the 1, 5, or $10 \%$ levels is reported as superscripts 1,5 , and ${ }^{*}$, respectively. 
Figure 1: Aggregate Corporate Cash - Flow of Funds

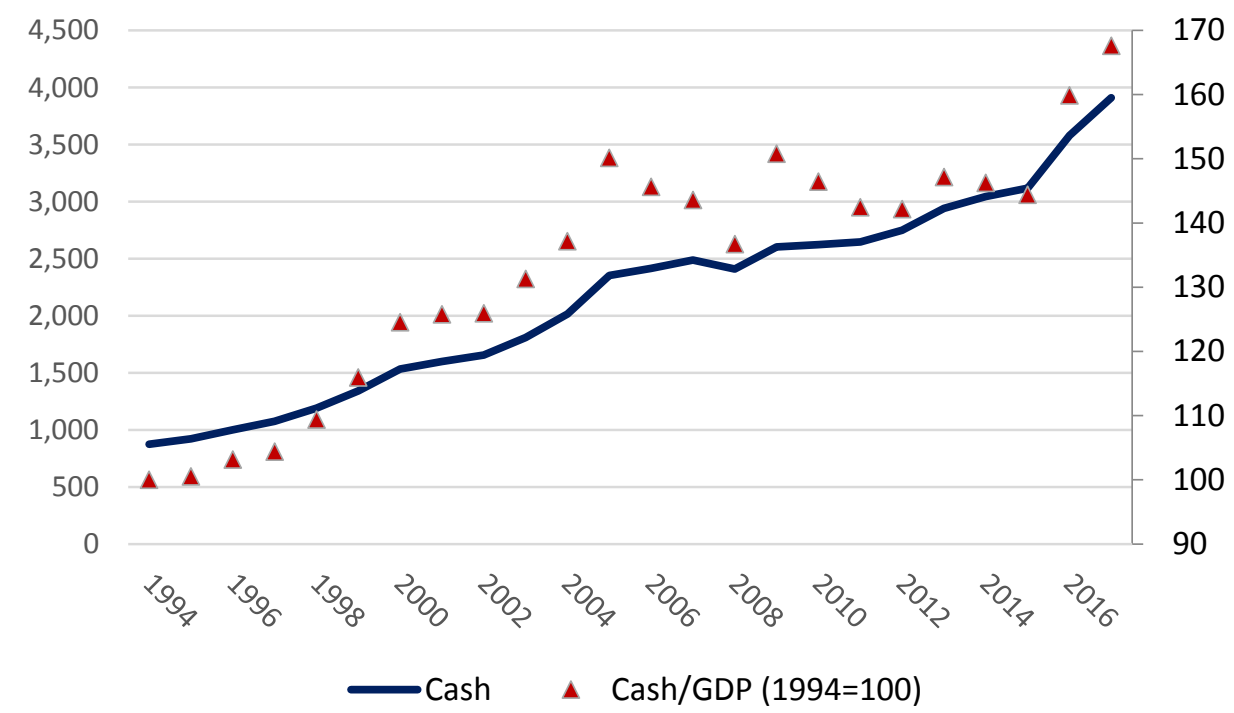

Notes:

The data is from the Federal Reserve Flow of Funds, Table L. 102 Nonfinancial Business (June 1, 2018). We summed rows 2 through 11. This includes checking and savings accounts of nonfinancial businesses as well as investment in debt securities (e.g. commercial paper, government bonds, and loans). The data is from 1994 to 2017. 
Figure 2: Domestic and Foreign Cash

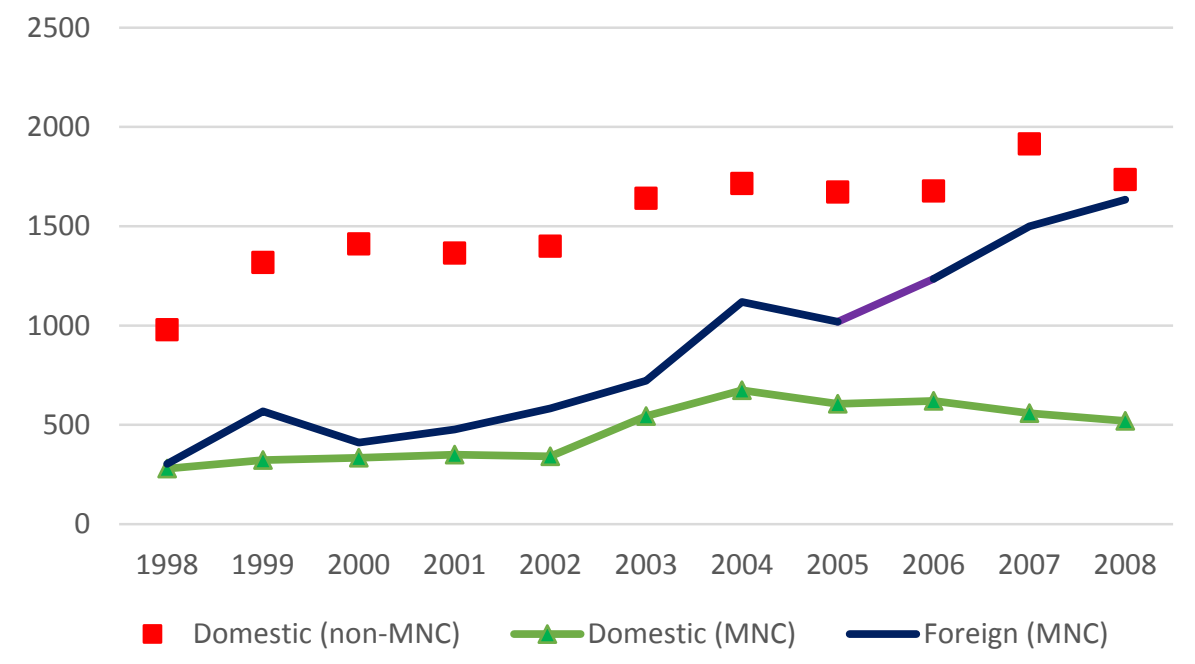

Notes:

The figure graphs the domestic cash of non-MNC and both the foreign and domestic cash for MNC in \$B. Total cash is from Compustat, and foreign cash is from the BEA (see paper for details). Domestic cash for MNC is the difference between total cash and foreign cash. Domestic cash levels of domestic firms increase by a factor of $1.8 \mathrm{x}$ while domestic cash levels of MNCs increase by a factor of $1.9 \mathrm{x}$ over the sample period. GDP increases by a factor of $1.3 \mathrm{x}$. The level of foreign cash (held by MNCs) increases by a factor of 5.4x. 
Figure 3: Corporate Tax Rates: US and Foreign Rates

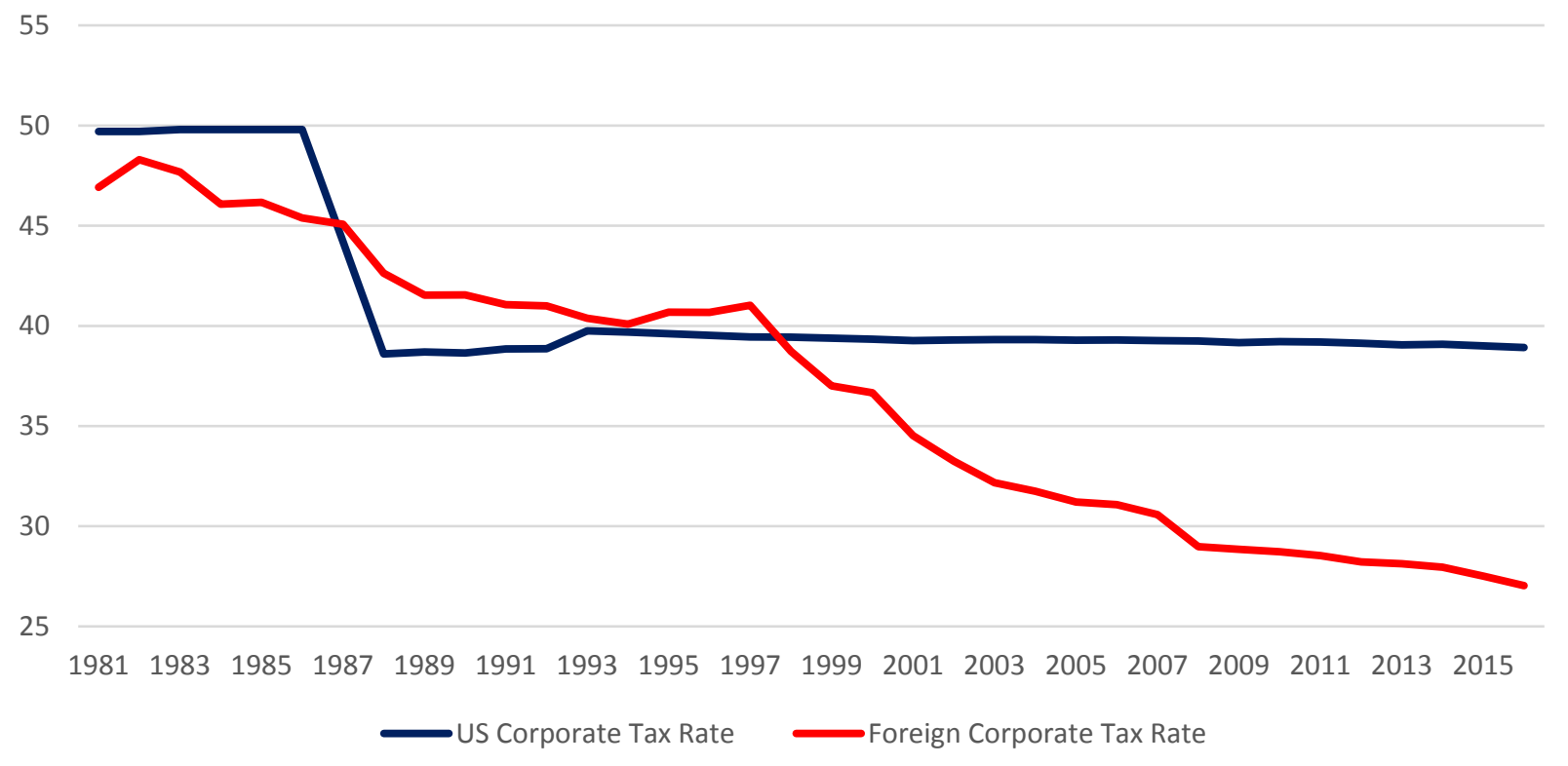

Notes:

The figure graphs the top US corporate tax rate and the average corporate tax rate across the following foreign countries: Australia, Belgium, Canada, Ireland, Italy, France, Germany, Japan, Luxembourg, the Netherlands, Switzerland, and the United Kingdom. These are the countries in the top 15 of cash holdings (see Table 2) where the tax rate data was available from the OECD website. ${ }^{42}$

${ }^{42}$ The top corporate tax rates are taken from the OECD web site (stats.oecd.org). The data is not reported for Japan before 1990 or for Luxembourg before 2000. These countries are excluded from the average in these years. 
Figure 4: The Growth of Related Sales

Panel A: Average Related Sales to GDP

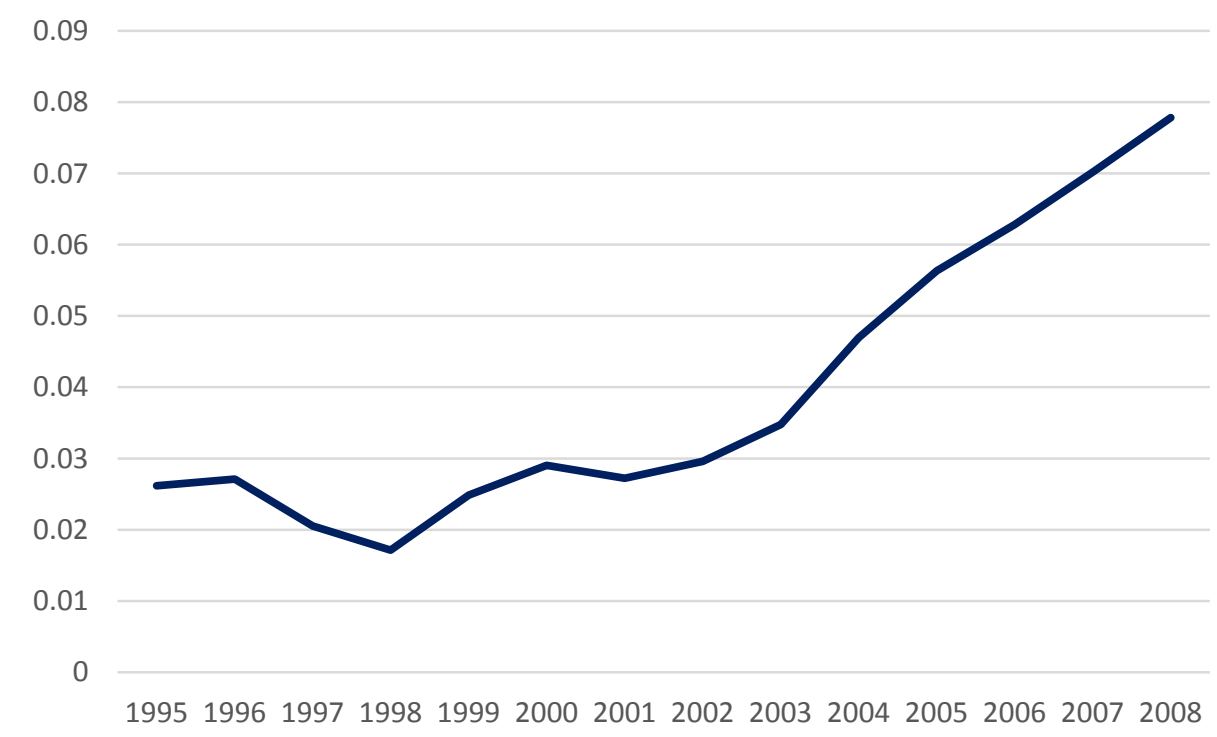

Panel B: Average Related Sales to GDP by Tax Haven Status

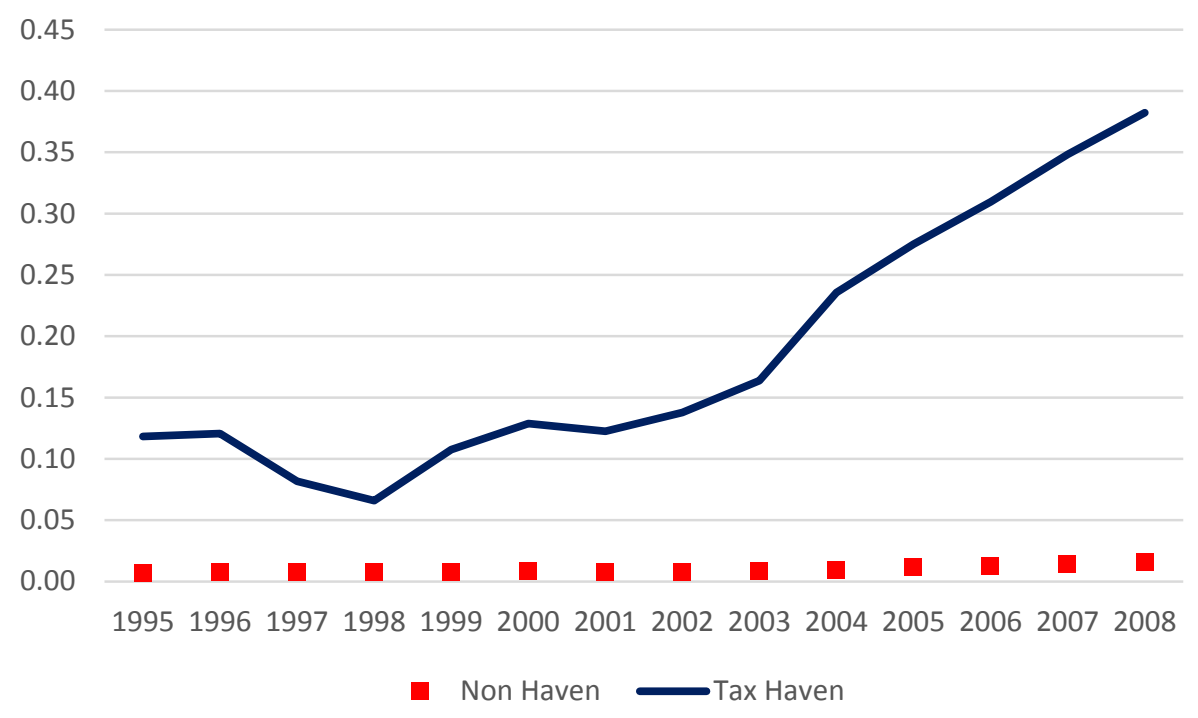

Notes:

For each country in our sample, we sum the related sales originating from all subsidiaries located in that country each year. We then divided this amount by the GDP of the country. The average (multiplied by 1M) is graphed for each year from 1995 to 2008 in Panel A. In Panel B, we graph the average ratio for countries classified as tax havens or not (as defined by the Global Policy Forum, see Dyreng and Lindsey, 2009). 
Figure 5: Foreign Cash of MNC by R\&D and Related Sales

Panel A: Total Foreign Cash

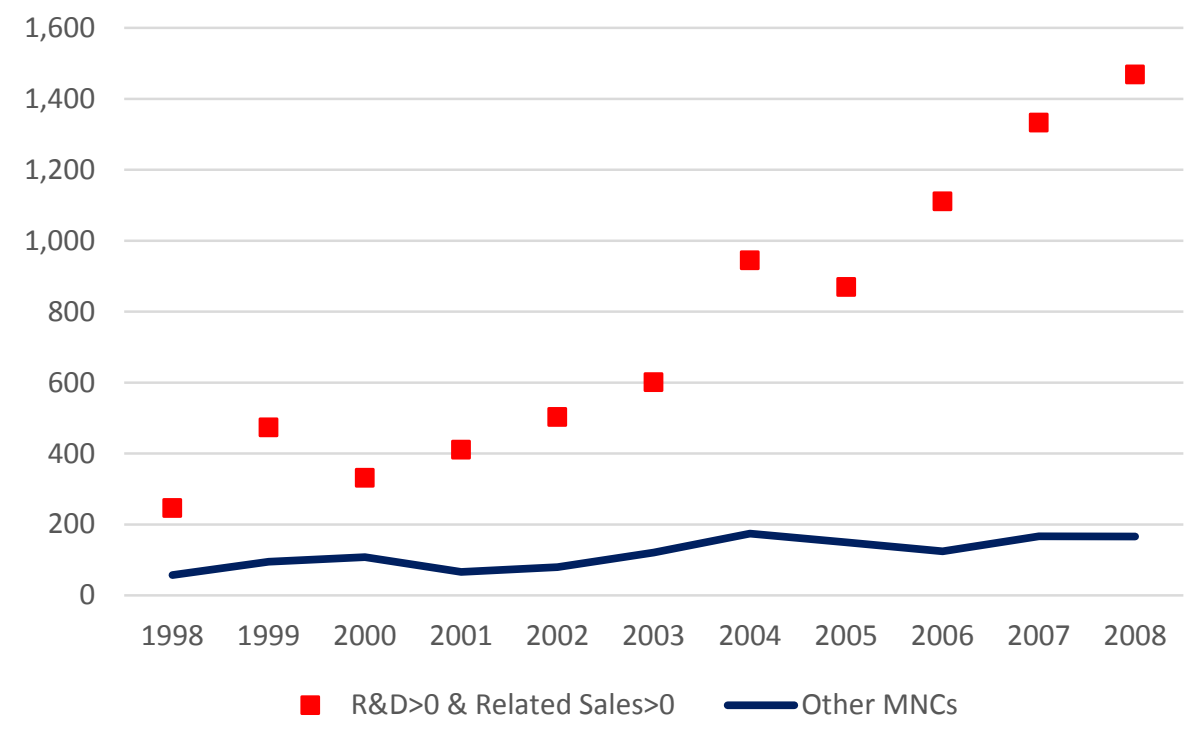

Panel B: Mean Foreign Cash/Assets

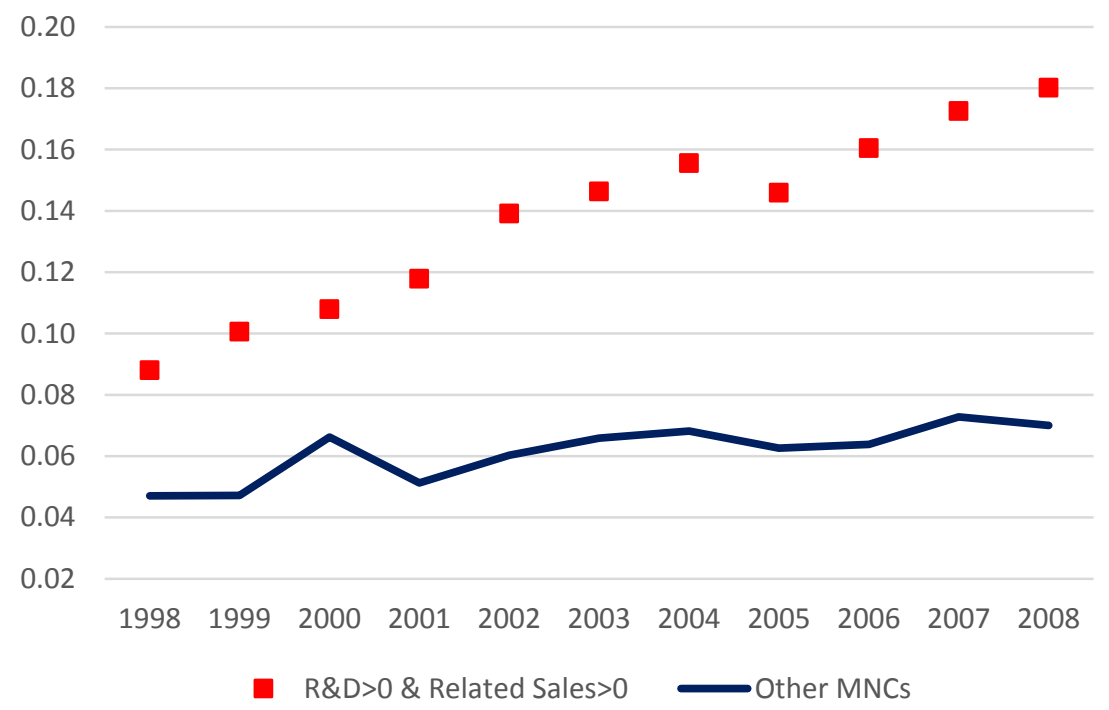

Notes:

We graph total foreign cash (Panel A) and the mean foreign cash to asset ratio (Panel B) for two samples: MNCs that report both positive (and non-missing) R\&D and positive related sales versus all other MNCs (either or both $R \& D$ and related sales are zero, or in the case of $R \& D$ missing). Related sales are subsidiary's revenue arising from sales to the other subsidiaries of the firm or to its parent. Total foreign cash is reported in \$B in Panel A. 
Figure 6: Average Percent of Income Earned by MNC in Their Foreign Subsidiaries

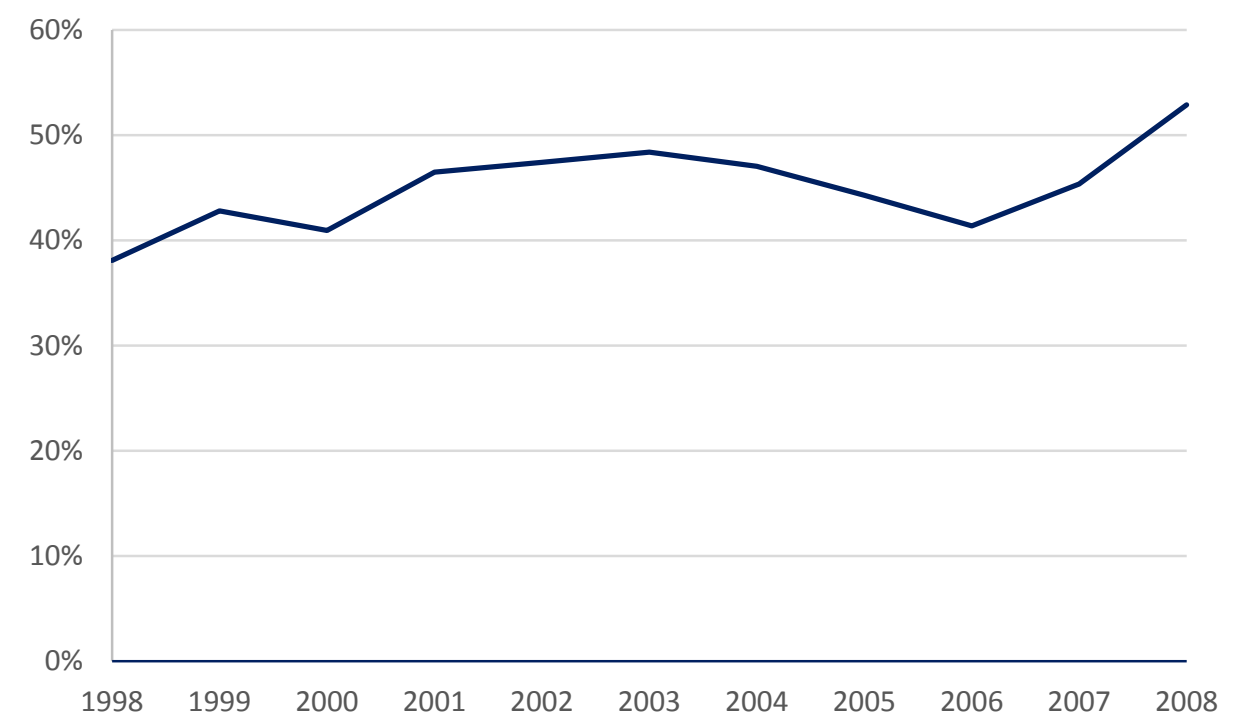

Notes:

The figure graphs the mean percent of MNCs' income that is earned in their foreign subsidiaries (see Table 6). 
Figure 7: Effective Tax Rates by Related Sales

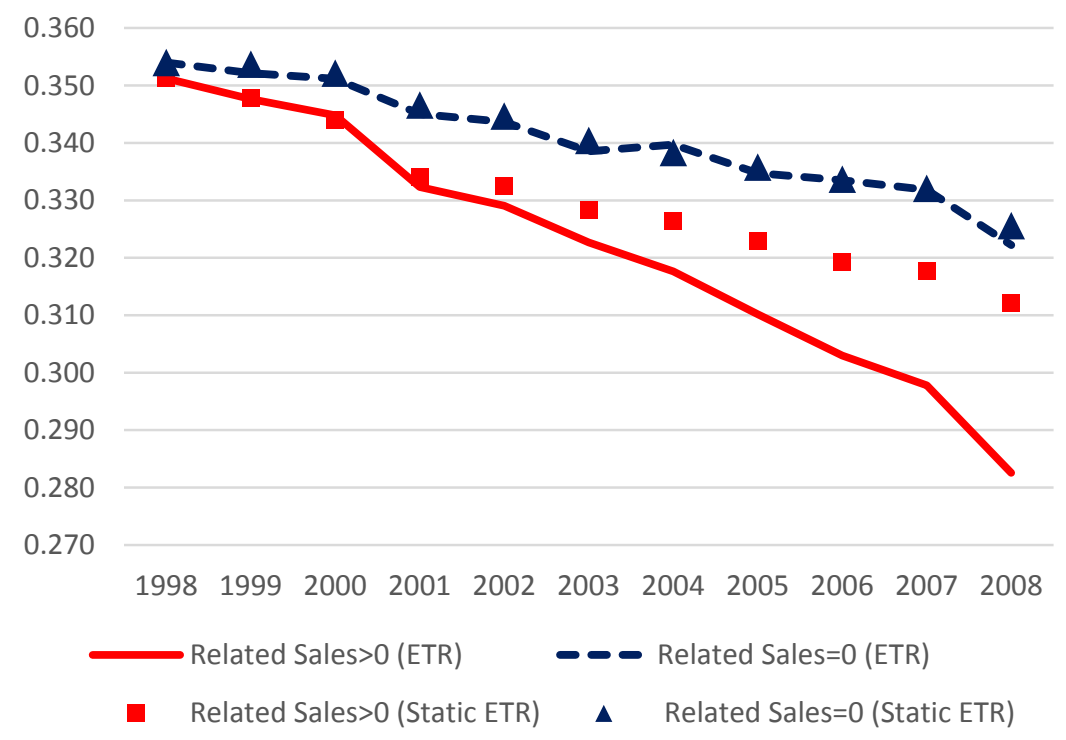

Notes:

We graph the effective tax rate for two samples: MNCs that report positive versus zero related sales. Related sales are subsidiary's revenue arising from sales to the other subsidiaries of the firm or to its parent. The effective tax rate is graphed for firms with positive related sales (solid line) and firms with zero related sales (dotted line). The effective tax rate falls over time because foreign countries lowered their statutory tax rates and because firms shifted income to low tax countries. To break out these two effects, we also graph the static effective tax rate for firms with related sales (squares) and firms with zero related sales (triangles). The static tax rate is calculated like the effective tax rate (equation 1) but using the income weights for the first year a firm enters the sample (e.g. 1998) for all years. The fall in the static effective tax rate is due only to reduction in foreign statutory tax rates. 